\title{
Synthesis and characterization of novel optically active, poly(ester-imide)s bearing calix[4]arene and amino acid moieties: ionophoric properties and extraction abilities towards alkali-metal cations
}

\author{
Abdol-Reza Hajipour, ${ }^{12 *}$ Sakineh Habibi \\ ${ }^{1}$ Department of Pharmacology, University of Wisconsin, Medical School, 1300 \\ University Avenue, Madison, 53706-1532, WI, USA \\ $2^{*}$ Pharmaceutical Research Laboratory, College of Chemistry, Isfahan University of \\ Technology, Isfahan 84156, IR Iran; tel.: +98 311 3913262; fax: +983113912350; e- \\ mail: Haji@cc.iut.ac.ir
}

(Received: 30 November, 2008; published: 07 February, 2010)

\begin{abstract}
Optically active poly(ester-imide)s (PEls) containing upper rim calix[4]arene were prepared in good yield by polycondensation reactions of distal calix[4]arene diol with some optically active diacid chlorides. Pyromellitic dianhydride (3) was reacted with chiral amino acids (4a-4e) to obtain the resulting imide-acids (6a-6e). The compounds (6a-6e) were converted into the corresponding diacid chlorides (7a-7e). The polycondensation reactions of calixarene diol with optically active compounds $7 \mathrm{a}-7 \mathrm{e}$ were carried out by two methods: bulk polycondensation under microwave irradiation and solution polycondensation in a system of triethyl amine (TEA)/dichloromethane $\left(\mathrm{CH}_{2} \mathrm{Cl}_{2}\right)$. The optically active PEls had good yield and moderate inherent viscosity ranging between $0.18-0.38 \mathrm{dL} / \mathrm{g}$. The extraction ability measurements of PEls towards alkali metal cations $\left(\mathrm{Na}^{+}, \mathrm{K}^{+}, \mathrm{Cs}^{+}\right)$and $\mathrm{Ag}^{+}$showed a remarkable efficiency and selectivity toward $\mathrm{Ag}^{+}$.

Keywords: Calixarenes, Condensation polymerization, lonophores, Optically active, Poly(ester-imide)s
\end{abstract}

\section{Introduction}

Amino acids are constituents of proteins, typical biological polymers, and not only biologically important but also useful as chiral auxiliaries and building blocks in organic synthesis [1, 2]. Amino acid-based synthetic polymers are expected to show biocompatibility and biodegradability similar to polypeptides [3, 4].

Chiral polymers including those bearing main- or side chain amino acid units are used widely in the pharmaceutical industry for enantio-selective separation of drugs. This is achieved mainly via the use of chiral polymers as the stationary phase in chromatography or electrophoresis. Apart from chiral separation, biocompatible amino acid containing polymers are used in drug delivery systems [5].

The interest in calix[4]arene chemistry is rapidly increasing because its derivatives can form inclusion complexes with cations or with neutral molecules [6]. The parent p-tert-butyl calix[4]arene (1) contains two interesting substructures [7]. At lower rim four hydroxyl groups are present in very close proximity; these can be used for cation 
binding and transport $[8,9]$. The upper rim contains hydrophobic cavity that is potentially able to complex neutral substrates.

Calix[4]arenes can undergo chemical modifications either by reaction at the hydroxyl groups (lower rim) or by replacement of the tert-butyl groups (upper rim) by the other substituents [10]. Modified Calix[4]arenes have been found to be extremely useful in host-guest chemistry due to their tendency to form complexes with metal cations and neutral molecules. Based on this property, specific ligands for analytical chemistry [11], membranes [12], decontaminating agents for waste water [13], dendrimers and star polymers from calixarene core [14] have been prepared. Chemical modifications of Calix[4]arenes can also be exploited to keep macrocycle into a fixed conformation and at the same time to provide a special reactivity [15]. For instance the higher reactivity of one hydroxyl group with respect to the others is important for the construction of larger molecular assemblies such as functional polymers [16]. Thus polyacrylates [17], polyamides [18], and polysiloxanes [19] carrying calix[4]arenas derivatives as side group linked to the macromolecular chains have been described.

The introduction of suitably derivatized calixarene units in a polymer backbone can be a substantial advancement for the practical application of the intrinsic receptor properties of the macrocyclic system in a solid support. Calixarene containing polymers have been scarcely investigated. While some reports were dealing with the introduction of calixarene moieties as appendages of polymer chains [20], others described the preparation of polymers containing calixarenes in the backbone [21].

Poly(ester-imide)s (PEI)s posses desirable characteristics with the moieties of both polyimides and polyesters such as high thermal stability and good mechanical properties as well as easy processability [22-27].

In the last decades, many examples in the literature have reported the successful application of microwave (MW) energy leading to accelerated synthesis of different classes of organic compounds [28, 29] as well as macromolecules [30].

Nowadays, the use of MWs to improve classic organic syntheses has become very popular because it very often leads to higher yields, high selective activation of compounds, shorter reaction times, as well as the promotion of a new reaction [31].

Because of the importance of optically active polymers with amino acid moieties and calixarene based polymers, in this paper a new series of optically active PEls were synthesized using an equimolar amount of calix[4]arene diol in a fixed cone conformation and optically active diacid chlorides $7 \mathrm{a}-7 \mathrm{e}$ by bulk polycondensation using microwave irradiation and solution polymerization in the presence of TEA as a catalyst and $\mathrm{CH}_{2} \mathrm{Cl}_{2}$ as a solvent. It is worth noting that the retention of the cone conformation along the polymer chain has been reported to impart specific ionophoric properties to the calix[4]arene moieties towards alkali metal cations [32].

These novel polymers containing calix[4]arene moieties in their backbone are useful in the development of artificial membranes for the selective extraction of alkali metal cations from aqueous media into organic solvents and chiral stationary phases for separation of chiral natural ionic materials.

\section{Results and Discussion}

The lower rim calix[4]arene diol (2) was designed as a suitably derivatized calix[4]arene existing in the fixed cone conformation owing to the extensive $\mathrm{O}$ alkylation of the phenolic oxygens [33]. The different acidity of the phenolic hydroxyl 
groups is a well known special feature of calix[4]arenes [34] allowing the selective 1,3-derivatization at either the lower or upper rim (Scheme 1).

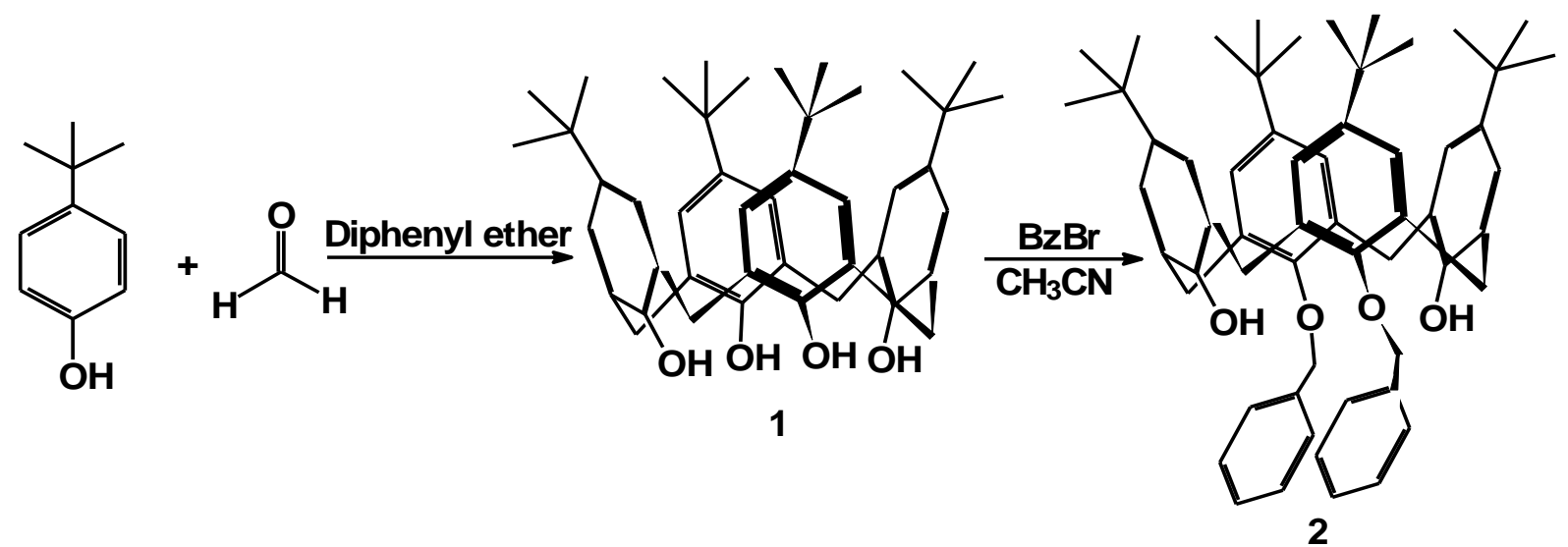

Scheme 1. Synthesis of p-tert-butyl calix[4]arene diol (2).

Diol (2) has a fixed cone conformation, as proved by its ${ }^{1} \mathrm{H}$ NMR spectrum which exhibited the signals for the equatorial and axial protons of the methylene bridges as doublets at 3 and 4 ppm, respectively [35]. FTIR and ${ }^{1} \mathrm{H}$ NMR spectra of calix[4]arene diol (2) has been shown in Figures 1 and 2.

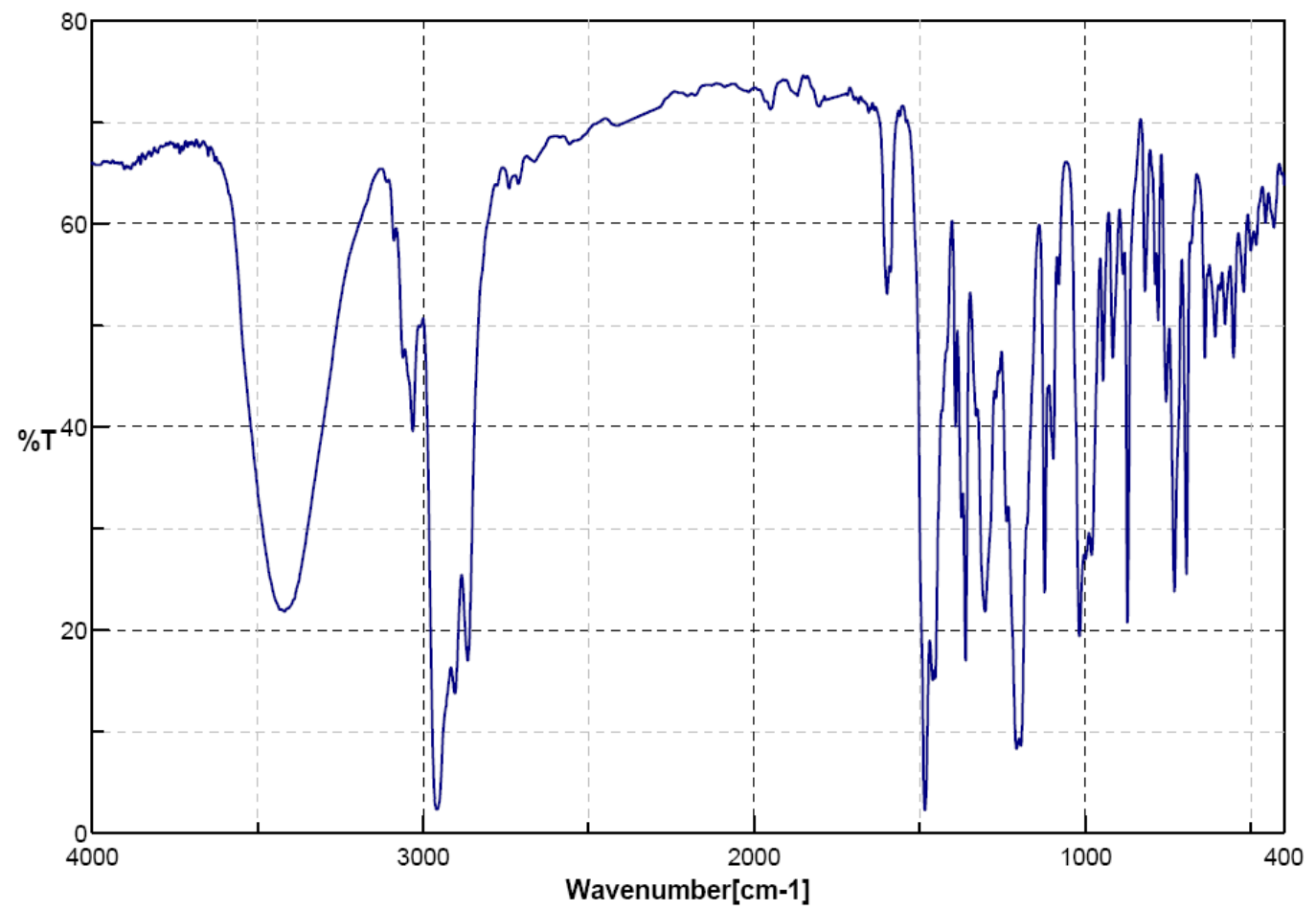

Fig. 1. FTIR spectrum of calix[4]arene diol (2).

While some polymeric calixarene derivatives have been reported over the years, quite surprisingly there are very few examples of optically active polymers bearing the calixarene moiety. Given the high chemical, mechanical and thermal character of the imide groups along with biodegradability of amino acids and their biological 
properties we envisioned the introduction of imide moieties in distal calix[4]arenes diol (2) as an entry to a new class of optically active receptors for metal cations. Hence, condensation reactions of pyromellitic dianhydride (3) with two moles of optically active amino acids L-alanine (4a), L-phenyl alanine (4b), L-leucine (4c), Lisoleucine (4d) and L-methionine (4e) in acetic acid afforded the corresponding optically active imide-diacids 6a-6e (Scheme 2) in $81-96 \%$ isolated yields. FTIR spectrum of diacid (6b) has been shown in Figure 3 as an example.
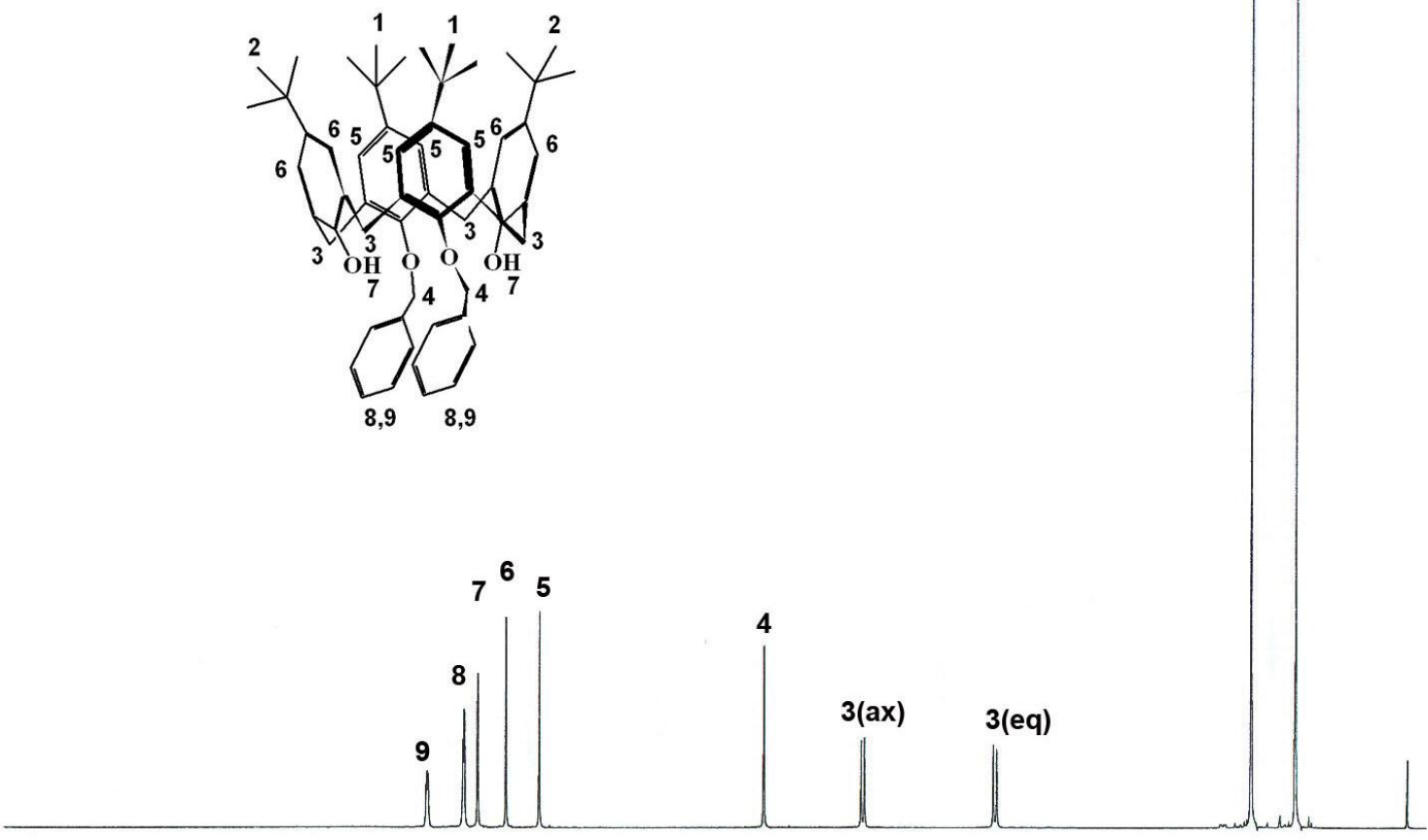

ppm

Fig. 2. ${ }^{1} \mathrm{H}$ NMR spectrum $(500 \mathrm{MHz})$ of calix[4]arene diol (2).

The symmetric diacids (6a-6e) were converted to the corresponding diacid chlorides (7a-7e) by reaction with thionyl chloride. The monomers (7a-7e) were purified by washing with $\mathrm{n}$-hexane. For synthesis of $\mathrm{N}, \mathrm{N}$ '-(pyromellitoyl)-bis-L-methionine diacid chloride (7e) less amount of thionyl chloride (5/1 molar ratio of thionyl chloride to diacid) was used and diluted with dry dichloromethane to perform the reflux under mild conditions. Chemical structure and purity of the optically active monomers (7a-7e) were proved using FTIR spectroscopy and melting point. FTIR spectrum of diacid chloride (7b) is shown in Fig. 3 and compared with the spectrum of diacid (6b).

PEls (8a-9e) were synthesized by solution and bulk polycondensation reactions of an equimolar mixture of monomers (7a-7e) with calix diol (2) (Scheme 3). 

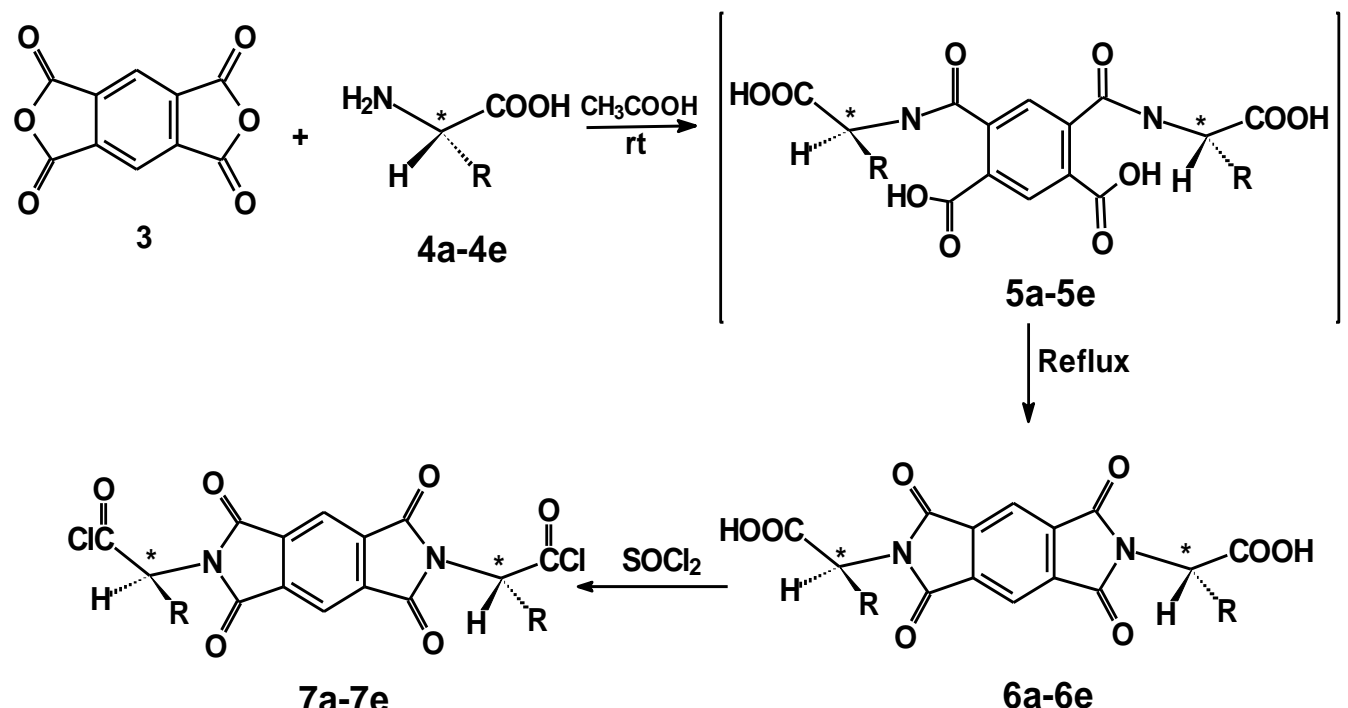

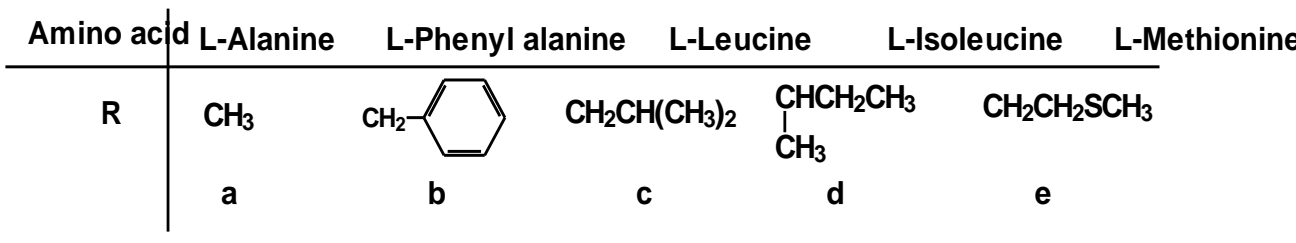

Scheme 2. Synthesis of optically active diacid chlorides (7a-7e).

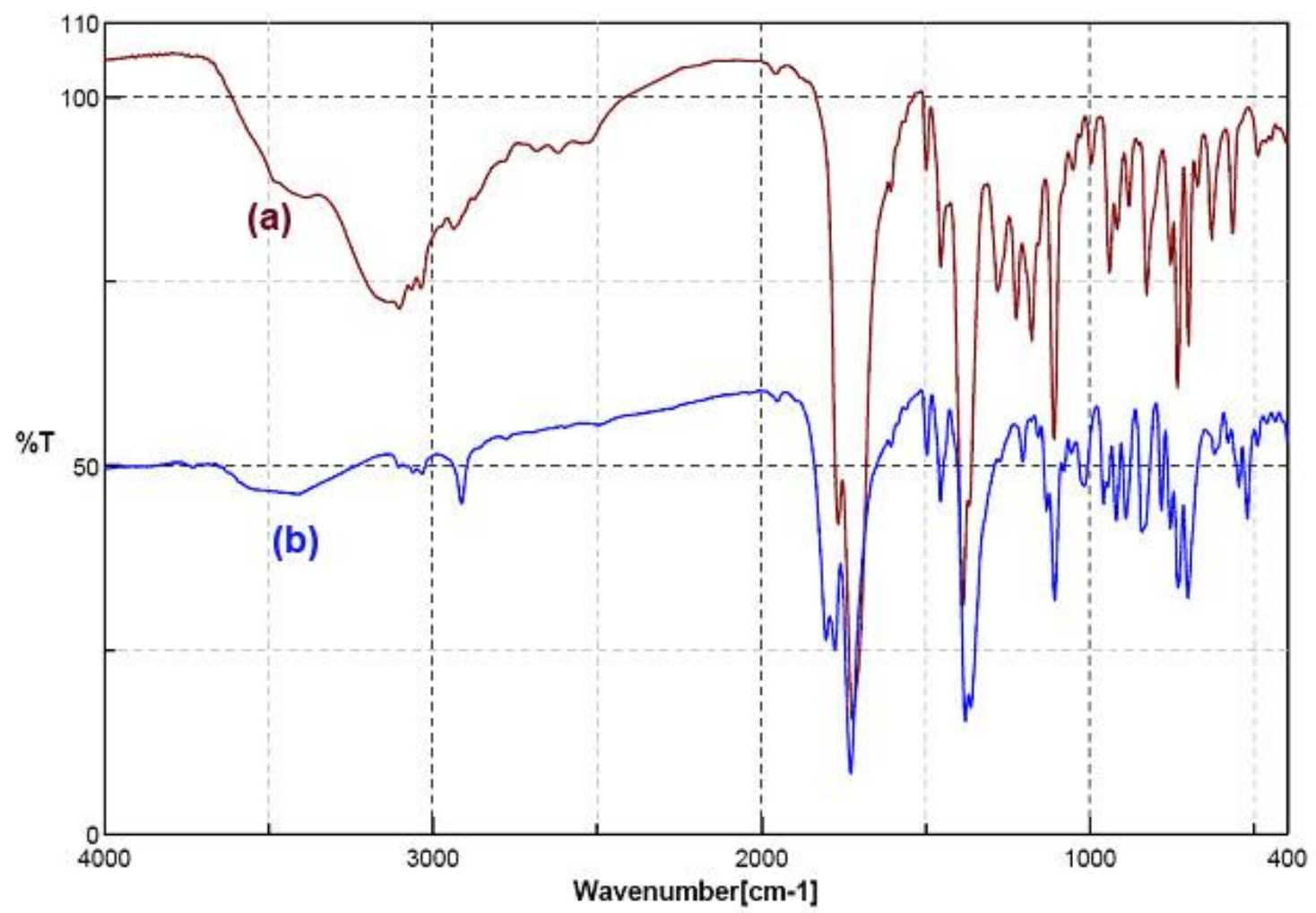

Fig. 3. FTIR spectrum of (a) diacid (6b) and (b) diacid chloride (7b). 


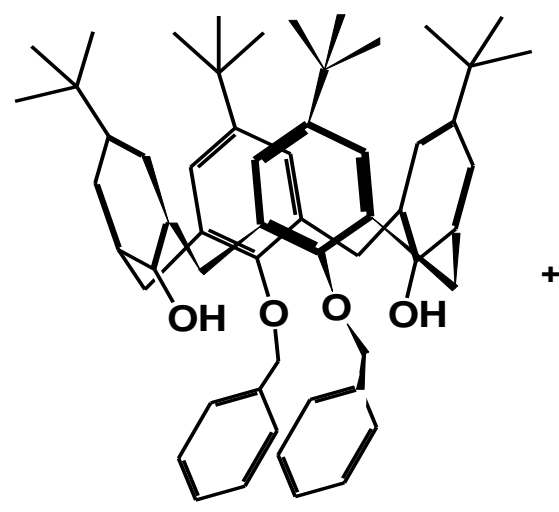<smiles>[R][C@H](C=O)n1c(=O)c2cc3c(=O)n([C@H]([R])[C@@H]([2H])Cl)c(=O)c3cc2c1=O</smiles>

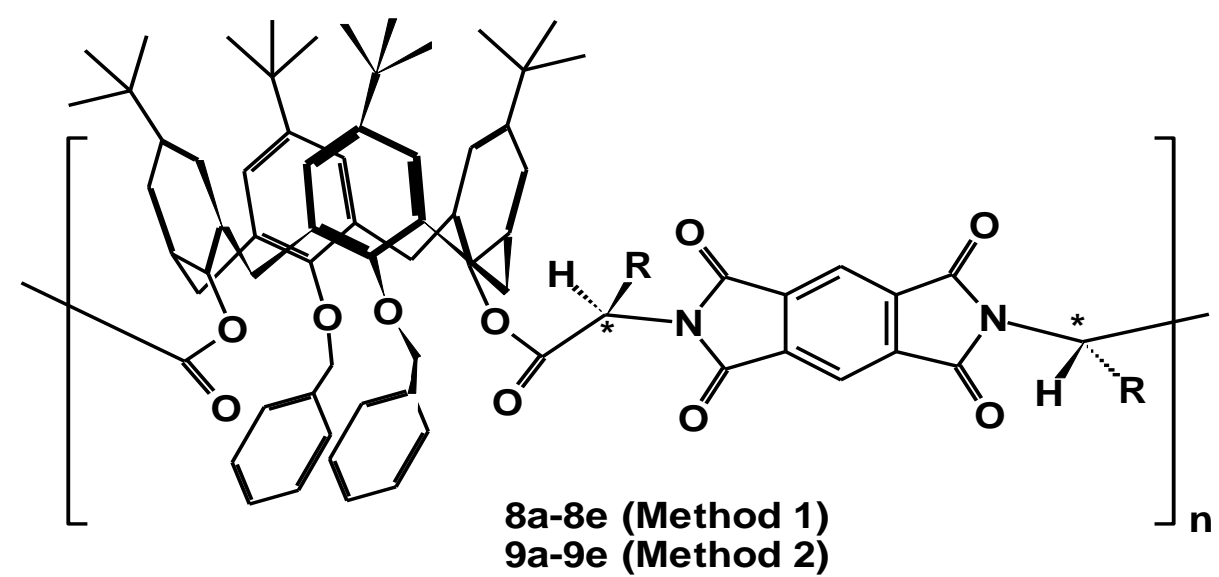

Scheme 3. Synthesis of PEIs (8a-9e).

In first method the bulk polymerization of optically active monomers (7a-7e) and calix[4]arene diol (2) was carried out using microwave irradiation with a controlled time and temperature schedule. We used a Milestone microwave apparatus for polymerization reactions. The best conditions for this method was 5 min at rt-50 ${ }^{\circ} \mathrm{C}$ $(1000 \mathrm{~W}), 5 \mathrm{~min}$ at $50-100{ }^{\circ} \mathrm{C}(1000 \mathrm{~W})$ and $5 \mathrm{~min}$ at $100-110^{\circ} \mathrm{C}(1000 \mathrm{~W})$. The reaction was at constant power with varying temperature. With lower irradiation powers the polymers had low molecular weights, and at higher temperatures and times there were no longer polymer chain growth and decomposition of polymers occurred.

Tab. 1. Some physical properties of PEIs (8a-8e) prepared by method 1 .

\begin{tabular}{ccccccc}
\hline \multirow{2}{*}{ Monomer } & \multicolumn{6}{c}{ polymer } \\
\cline { 2 - 7 } & Polymer code Yield $(\%)$ & $\eta_{\text {inh }}(\mathrm{dL} / \mathrm{g})^{a}$ & {$[\alpha]_{\mathrm{D}}^{25}$} & m.p. $\left({ }^{\circ} \mathrm{C}\right)^{\mathrm{c}}$ & Color $^{\mathrm{d}}$ \\
\hline 7a & $\mathbf{8 a}$ & 80.1 & 0.31 & -10.6 & 148 & $\mathrm{~B}$ \\
7b & $\mathbf{8 b}$ & 75.2 & 0.25 & -25.0 & 180 & $\mathrm{PY}$ \\
7c & $\mathbf{8 c}$ & 85.3 & 0.38 & -2.8 & 186 & $\mathrm{Y}$ \\
7d & $\mathbf{8 d}$ & 85.1 & 0.36 & -8.9 & 172 & $\mathrm{PY}$ \\
7e & $\mathbf{8 e}$ & 80.0 & 0.31 & -45.9 & 240 & $\mathrm{~PB}$ \\
\hline
\end{tabular}

\footnotetext{
${ }^{a}$ Measured at a concentration of $0.5 \mathrm{~g} / \mathrm{dL}$ in $\mathrm{CHCl}_{3}$ at $25^{\circ} \mathrm{C}$.

${ }^{b}$ Measured at a concentration of $0.5 \mathrm{~g} / \mathrm{dL}$ in $\mathrm{CHCl}_{3}$ at $25^{\circ} \mathrm{C}$

${ }^{c}$ Started to melt at this temperature, complete melting at higher temperature.

${ }^{\mathrm{d}} \mathrm{Y}=$ Yellow, $\mathrm{PY}=$ Pale Yellow, $\mathrm{PB}=\mathrm{Pale}$ Brown, $\mathrm{B}=$ Brown.
} 
The PEls (8a-8e) were obtained in good yields (75-85\%) and moderate inherent viscosities $(0.25-0.38 \mathrm{dL} / \mathrm{g})$. Also they were optically active and soluble in organic solvents such as $\mathrm{CHCl}_{3}, \mathrm{CH}_{2} \mathrm{Cl}_{2}$, THF, DMF and polar aprotic solvents but insoluble in water, $\mathrm{CH}_{3} \mathrm{OH}$ and nonpolar solvents. Some physical properties of PEls $(\mathbf{8 a}-\mathbf{8 e})$ is shown in Table 1. Elemental analysis data of PEls $(\mathbf{8 a - 8 e})$ is shown in Table 2.

Tab. 2. Elemental analysis data of PEls (8a-8e).

\begin{tabular}{llllll}
\hline Polymer & Formula & & $\mathrm{C}(\%)$ & $\mathrm{H}(\%)$ & $\mathrm{N}(\%)$ \\
\hline $\mathbf{8 a}$ & $\left(\mathrm{C}_{74} \mathrm{H}_{76} \mathrm{~N}_{2} \mathrm{O}_{10}\right)_{n}$ & Calcd & 77.06 & 6.64 & 2.43 \\
& $(1153)_{n}$ & Found & 76.33 & 6.63 & 2.15 \\
$\mathbf{8 c}$ & $\left(\mathrm{C}_{80} \mathrm{H}_{88} \mathrm{~N}_{2} \mathrm{O}_{10}\right)_{n}$ & Calcd & 77.64 & 7.17 & 2.26 \\
& $(1237)_{n}$ & Found & 76.84 & 6.90 & 1.89 \\
$\mathbf{8 d}$ & $\left(\mathrm{C}_{80} \mathrm{H}_{88} \mathrm{~N}_{2} \mathrm{O}_{10}\right)_{n}$ & Calcd & 77.64 & 7.17 & 2.26 \\
& $(1237)_{n}$ & Found & 77.46 & 6.95 & 1.99 \\
8e & $\left(\mathrm{C}_{76} \mathrm{H}_{80} \mathrm{~N}_{2} \mathrm{O}_{10} \mathrm{~S}_{2}\right)_{n}$ & Calcd & 73.28 & 6.47 & 2.25 \\
& $(1246)_{n}$ & Found & 74.09 & 6.18 & 1.55 \\
\hline
\end{tabular}

Tab. 3. Some physical properties of PEls (9a-9e) prepared by method 2 .

\begin{tabular}{ccccccc}
\hline & \multicolumn{7}{c}{ polymer } \\
\cline { 2 - 7 } Monomer & Polymer code & Yield $(\%)$ & $\eta_{\text {inh }}(\mathrm{dL} / \mathrm{g})^{a}$ & {$[\alpha]_{\mathrm{D}}^{25}$} & m.p. $\left({ }^{\circ} \mathrm{C}\right)^{\mathrm{c}}$ & Color $^{\mathrm{d}}$ \\
\hline 7a & 9a & 72.1 & 0.18 & -1.4 & 195 & $\mathrm{~B}$ \\
7b & 9b & 77.6 & 0.21 & -0.6 & 226 & $\mathrm{PY}$ \\
7c & 9c & 71.5 & 0.25 & -0.7 & 236 & $\mathrm{Y}$ \\
7d & 9d & 75.2 & 0.22 & -7.9 & 215 & PY \\
7e & 9e & 70.8 & 0.24 & -0.3 & 249 & PB \\
\hline
\end{tabular}

${ }^{a}$ Measured at a concentration of $0.5 \mathrm{~g} / \mathrm{dL}$ in DMF at $25^{\circ} \mathrm{C}$.

${ }^{b}$ Measured at a concentration of $0.5 \mathrm{~g} / \mathrm{dL}$ in DMF at $25^{\circ} \mathrm{C}$.

${ }^{\mathrm{C}}$ Started to melt at this temperature, complete melting at higher temperature.

${ }^{d} \mathrm{Y}=$ Yellow, $\mathrm{PY}=$ Pale Yellow, $\mathrm{PB}=$ Pale Brown, $\mathrm{B}=$ Brown.

Also we investigated the solution polycondensation of monomers (7a-7e) and (2) as second method. Due to good solubility of both monomers in $\mathrm{CH}_{2} \mathrm{Cl}_{2}$ we performed the reaction in this solvent in the presence of triethyl amine as a catalyst and acid scavenger. The solution of monomers (7a-7e) in dry $\mathrm{CH}_{2} \mathrm{Cl}_{2}$ was added drop wise to a solution of calix[4]arene diol (2) in $\mathrm{CH}_{2} \mathrm{Cl}_{2}$ in the presence of TEA and the reaction mixture was stirred for $30 \mathrm{~min}$ and refluxing conditions for $1 \mathrm{~h}$. During refluxing the polymer was precipitated in the reaction mixture. It is interesting that these polymers were insoluble in $\mathrm{CH}_{2} \mathrm{Cl}_{2}, \mathrm{CHCl}_{3}$ but soluble in polar aprotic solvents like DMF. The PEls (9a-9e) obtained in the yields of $70-85 \%$ and inherent viscosities of $0.18-0.25$ $\mathrm{dL} / \mathrm{g}$. The optical activity and molecular weight of these polymers were lower than method 1. Some physical properties of PEls $9 a-9 e$ is shown in Table 3 . The solubility of all PEls is shown in Table 4.

All polymers were fully characterized by FTIR, ${ }^{1} \mathrm{H}$ NMR and elemental analysis. The FTIR and ${ }^{1} \mathrm{H}$ NMR spectra of polymers (8a) and (8e) are shown in Figures 4 and 5 , respectively. 
Tab. 4. The solubility properties of PEls (8a-9e).

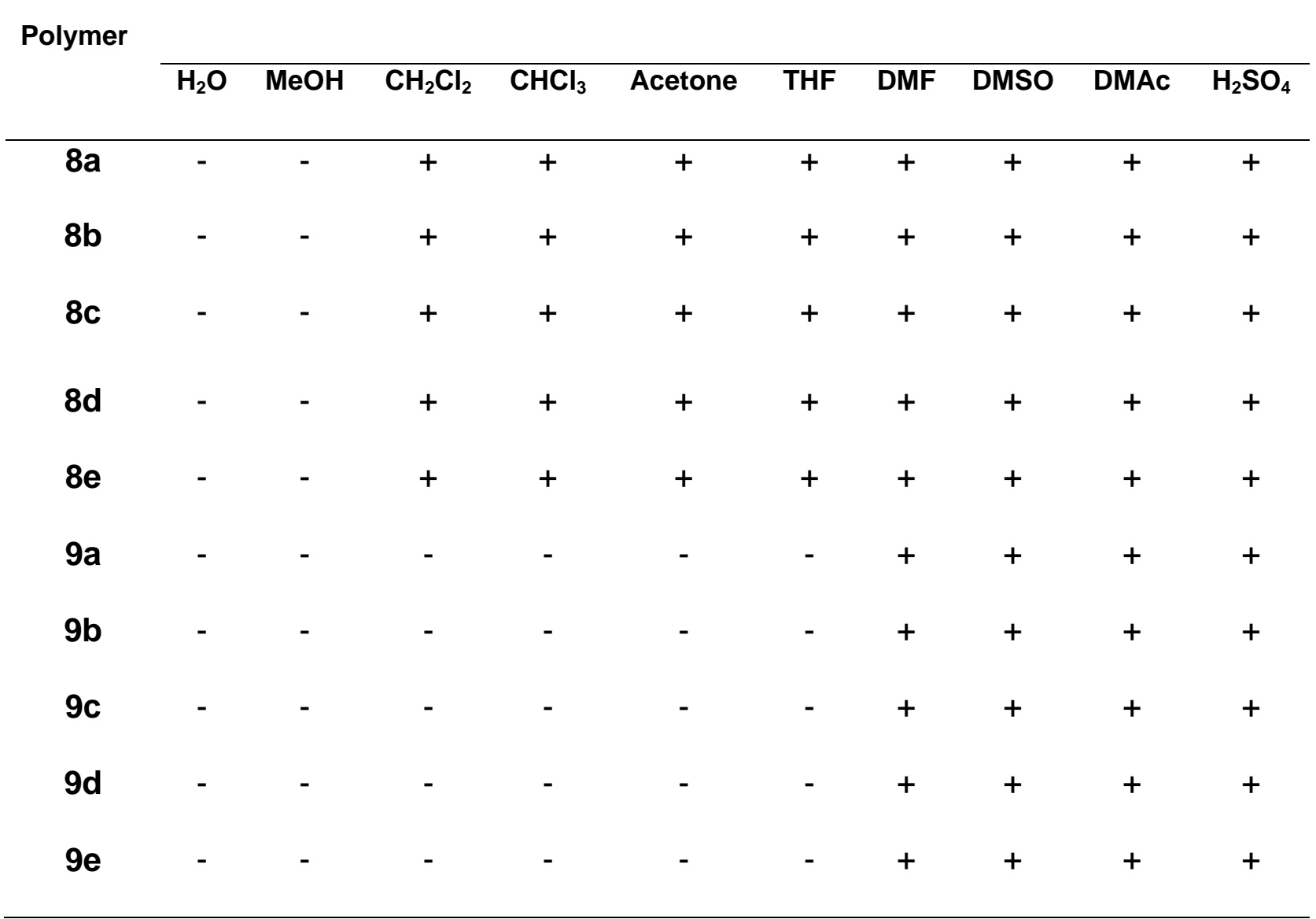

${ }^{\text {a }}$ Concentration: $5 \mathrm{mg} \mathrm{ml}^{-1}$; +: Soluble at room temperature, -: Insoluble

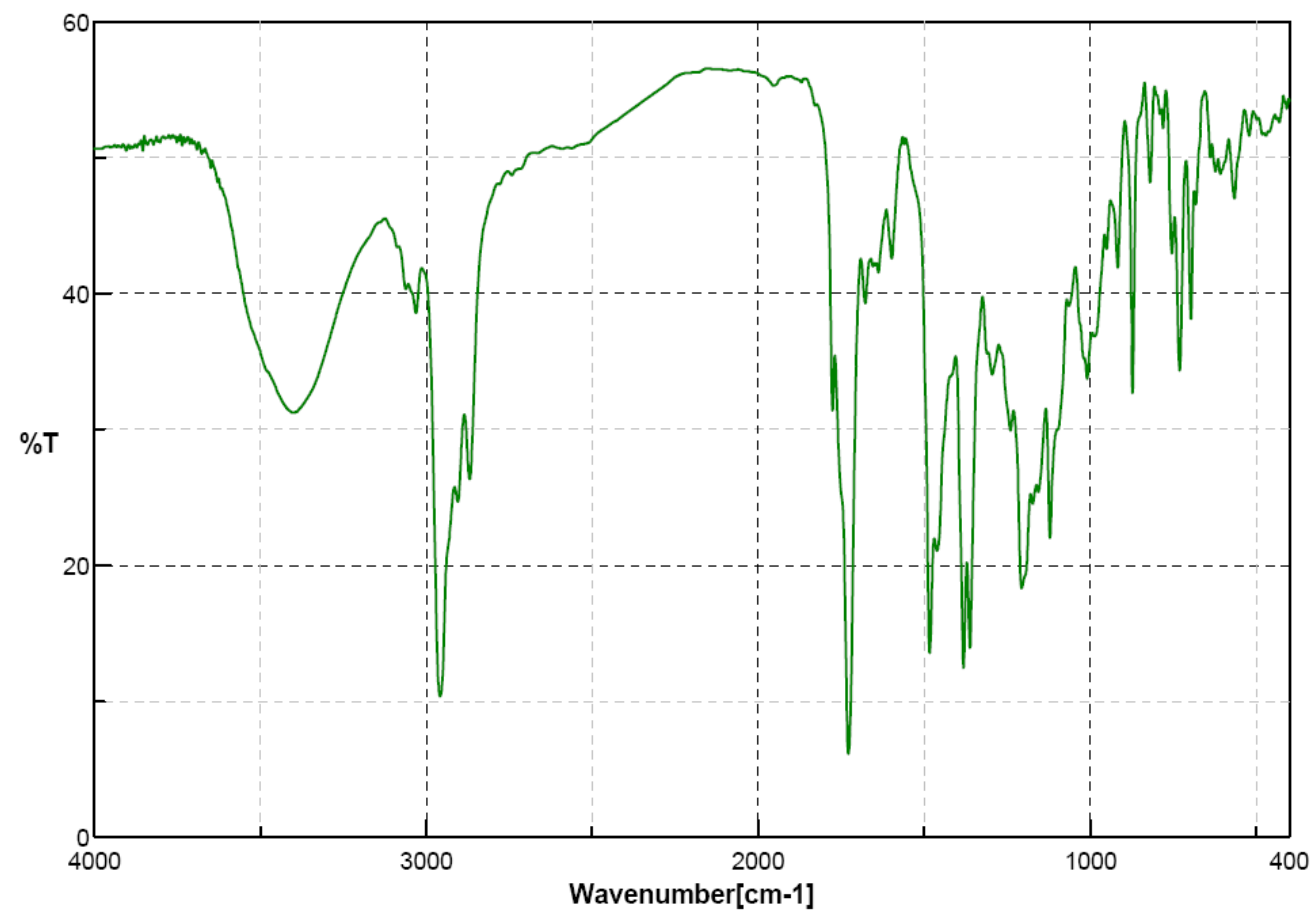

Fig. 4. FTIR spectrum of PEI (8a). 

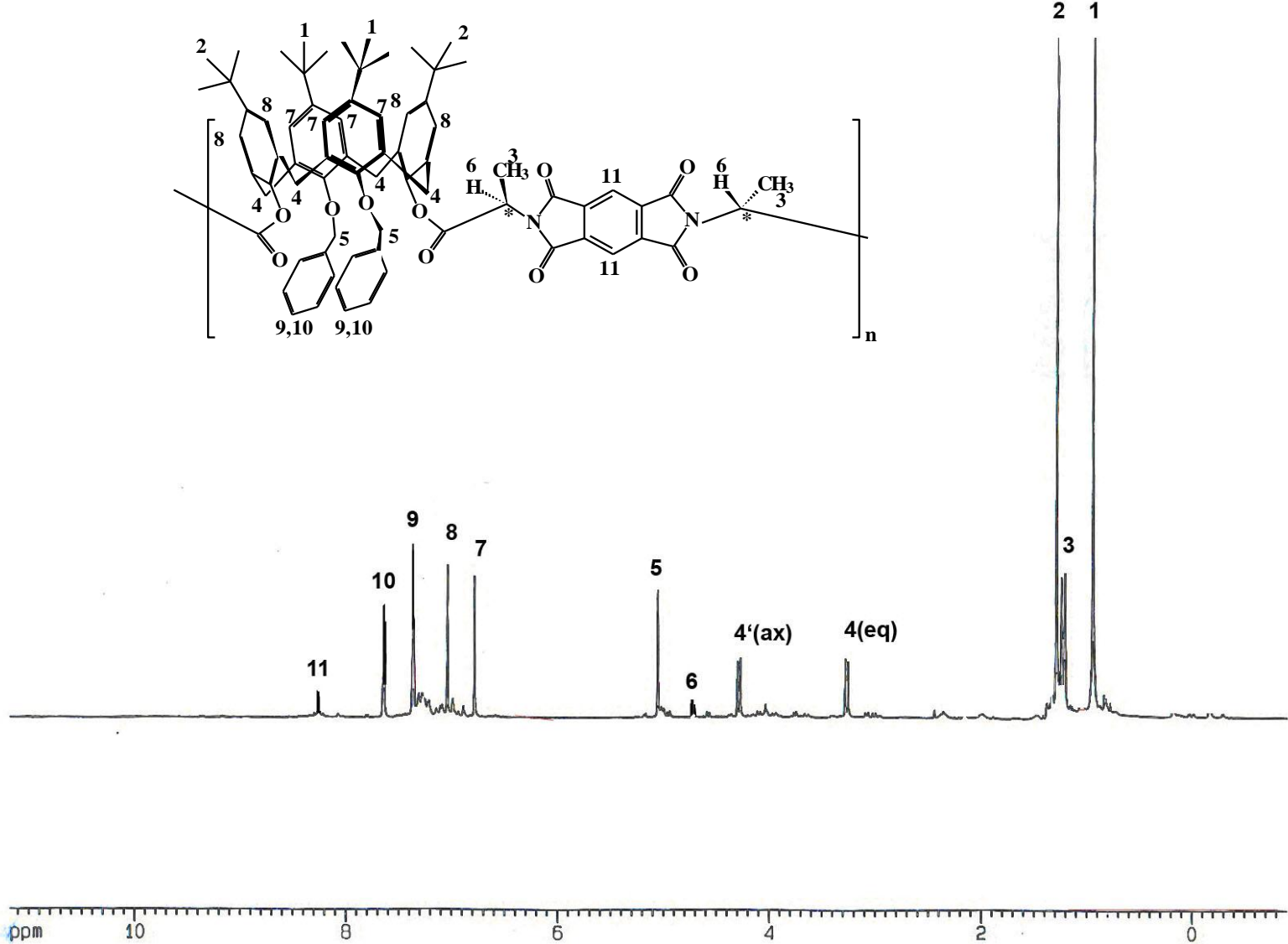

Fig. 5. ${ }^{1} \mathrm{H}$ NMR $(500 \mathrm{MHz})$ spectrum of PEI (8a).

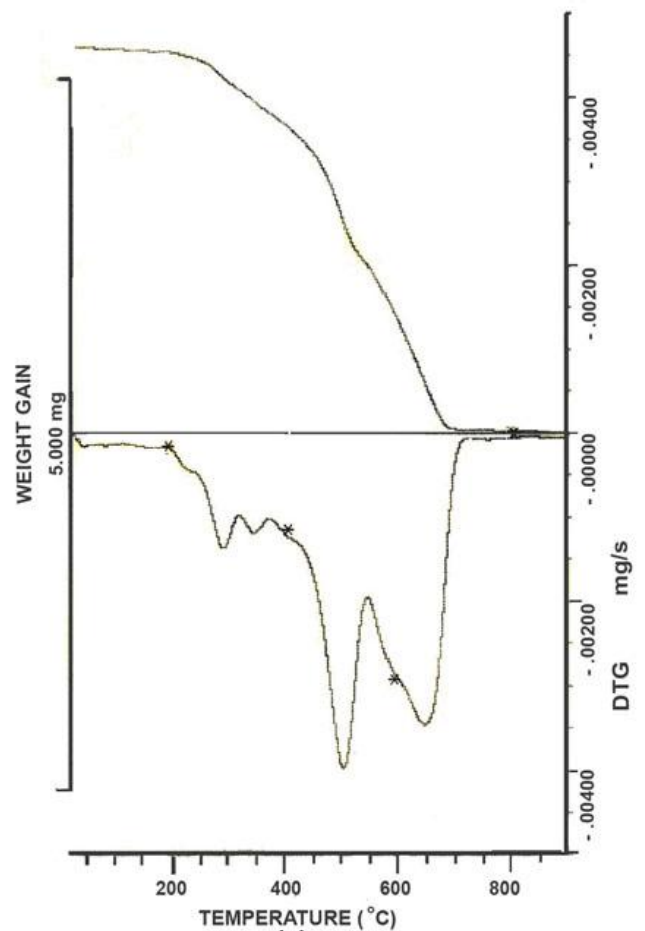

(a)

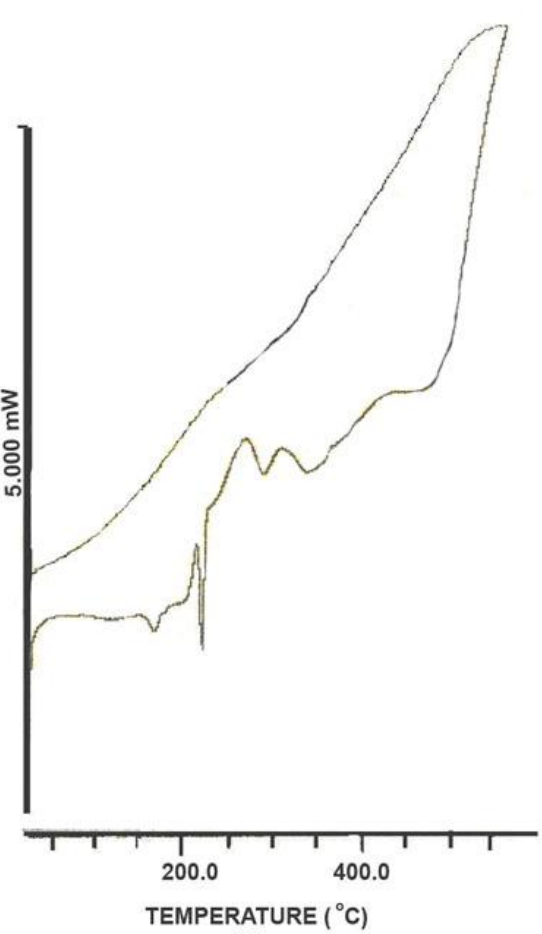

(b)

Fig. 6. (a) TGA thermogram and (b) DSC thermogram of PEI 9c. 
The ${ }^{1} \mathrm{H}$ NMR spectra of these PEls showed typical signal patterns (two doublets) at 3.3 and $4.3 \mathrm{ppm}$, which were assigned to the equatorial and axial protons of the methylene bridges of the calix[4]arene residue adopting the cone conformation which was retained during the polymerization. Also the characteristic signals of four $t$-butyl groups in calix[4]arene moieties were appeared as two sharp peaks at 0.95 and 1.29 ppm in ${ }^{1} \mathrm{H}$ NMR spectra of all polymers which is an evidence for introduction of calix[4]arene moieties in the polymer chain.

The thermal properties of PEI (9c) were evaluated by means of TGA/DTG and DSC analysis under nitrogen atmosphere. The PEI (9c) exhibited good resistance to thermal decomposition up to 200 and $230{ }^{\circ} \mathrm{C}$ and began to decompose gradually above those temperatures. TGA thermogram of this polymer showed three thermal decomposition steps: first step with peak temperature of $289.3{ }^{\circ} \mathrm{C}$ and end temperature of $315.3^{\circ} \mathrm{C}$ with $10.3 \%$ weight loss, second step with peak temperature of $497.3^{\circ} \mathrm{C}$ and end temperature of $540.7^{\circ} \mathrm{C}$ with $47.8 \%$ weight loss and third step with peak temperature of $640.3^{\circ} \mathrm{C}$ and end temperature of $709.7^{\circ} \mathrm{C}$ with $46.2 \%$. In DSC thermogram of polymer $(9 \mathrm{c})$ two endothermic regions were observed at around 200 and $250{ }^{\circ} \mathrm{C}$ which corresponded to $T_{g}$ and $T_{m}$ respectively. TGA and DSC thermogram of PEI (9c) is shown in Figure 6.
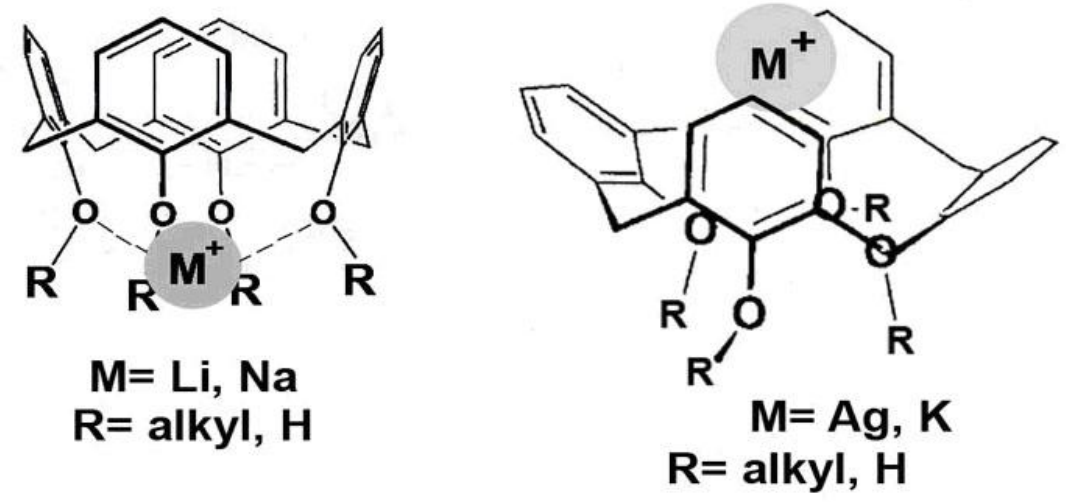

Fig. 7. Complexation of the calix[4]arene derivative (in a fixed cone conformation) with alkali metal and silver cations.

Calix[n]arenes are well known to act as ligands or to host various species including small organic molecules, metal cations, and some anions. For example, compounds bearing four ether groups at lower rim showed good binding properties towards alkali metal cations but were inert towards alkaline earth metal ions, divalent and trivalent metal cations [36-38]. This binding selectivity was related both to the macrocycle ring size and its conformation. However a fine tuning of the cation binding was possible by varying the alkoxy groups at the lower rim [34]. The complexation of transition metals has been reported to be favored by the introduction of functional groups containing soft donor atoms such as nitrogen, sulfur, and phosporus [39]. Alkoxy lower rim substituted calix[4]arene derivatives have been shown to bind silver cations [36]. In this case, a cation- $\pi$ interaction appeared to be operative [42] since the silver ion was bound in a sandwich-like manner between two opposite phenyl rings. Quite interestingly the partial-cone conformation of the macrocycle provided the best arrangement for the silver and potassium cation binding [36, 37, 41, 42]. Also it was reported that $\mathrm{Ag}^{+}$(and probably $\mathrm{K}^{+}$also) is bound to the upper rim through the interaction with one or two oxygens and two benzene rings in these conformers. 
These cationic guests are selectively included in the cone cavity and the preorganization of benzene rings is indispensable to the appearance of the "cation-m interaction" (Fig. 7) [42]. The selective $\mathrm{Ag}^{+}$recognition is an important requisite for several technological and biomedical applications such as photographic materials and radioimmunotherapy [43].

In this study we synthesized a diol derivative of $p$-tert-butyl calix[4]arene (2) and then we immobilized it through the imide and ester chain in the polymeric backbone to check the effectiveness of more than one calix[4]arene moiety together in a liquidliquid extraction system. We selected the PEIs $8 a-8 e$ for liquid-liquid extraction due to their good solubility in $\mathrm{CHCl}_{3}$. The extraction ability of calix[4]arene based PEls $8 \mathrm{a}-8 \mathrm{e}$ towards metal cations was measured using the Cram picrate method in a two-phase solvent system $\left(\mathrm{CHCl}_{3}-\mathrm{H}_{2} \mathrm{O}\right)$ [44]. The extraction ability data of imide-ester containing calix[4]arene based polymers expressed as percentages of extraction from water to chloroform, are collected in Table 5. First of all it has to be noticed that among the calix[4]arene based PEls, polymers (8a), (8d) and (8e) exhibited high levels of extraction abilities towards cation $\mathrm{Ag}^{+}$. Hence these extraction abilities have to be ascribed to the complexation ability of the calixarene macrocycle along with ester and ether groups. On the other hand, the calix[4]arene based PEls were good ionophores for $\mathrm{Na}^{+}$.

Tab. 5. Cation percentage extraction values of calix diol (2) and PEls (8a-8e) containing calix[4]arene moieties.

\begin{tabular}{ccccc}
\hline & \multicolumn{4}{c}{ Cations $^{\mathrm{b}}$} \\
\cline { 2 - 5 } Host $^{\mathrm{a}}$ & $\mathrm{Ag}^{+}$ & $\mathrm{Na}^{+}$ & $\mathrm{K}^{+}$ & $\mathrm{Cs}^{+}$ \\
\hline Calix diol (2) & 52.08 & 64.82 & 35.25 & 0.00 \\
8a & 53.10 & 18.45 & 10.49 & 0.00 \\
8b & 10.00 & 49.00 & 63.00 & 0.00 \\
8c & 18.44 & 19.81 & 4.17 & 0.00 \\
8d & 50.87 & 21.75 & 8.90 & 0.00 \\
8e & 55.70 & 11.82 & 7.68 & 0.00 \\
\hline
\end{tabular}

a The initial concentration was $2.0 \times 10^{-3} \mathrm{M}$ in $\mathrm{CHCl}_{3}$.
${ }^{\mathrm{b}}$ Concentration $1.0 \times 10^{-3} \mathrm{M}$ of the corresponding nitrate salts in aqueous solution containing $2.0 \times 10^{-5}$ $\mathrm{M}$ of picric acid.

These results demonstrate that PEls $(\mathbf{8 a}),(\mathbf{8 d})$ and $(\mathbf{8 e})$ have the highest selectivity for absorbing $\mathrm{Ag}^{+},(\mathbf{8 b})$ is the most selective for $\mathrm{K}^{+}$and all have good extraction ability toward $\mathrm{Na}^{+}$. Also we performed liquid-liquid extraction studies of some heavy metal cations $\left(\mathrm{Co}^{2+}, \mathrm{Hg}^{2+}, \mathrm{Cd}^{2+}\right.$ and $\left.\mathrm{Cu}^{2+}\right)$ but there was demonstrated no absorption ability towards these cations. Also all of the polymers and calix diol (2) had no extraction ability towards $\mathrm{Cs}^{+}$ion. This result showed that the binding ability of the compound (2) and PEls is related to the macrocycle ring and metal ion size. The UV curves of PEls for both initial picrate solutions and final solutions containing $\mathrm{Ag}^{+}$are demonstrated in Figure 8.

The advantage that can be foreseen with these polymers is their use as new materials for the extraction of alkali cations and silver ion in chiral natural media. On the other hand we can use these compounds both as ion selective polymers for ion separation and as chiral stationary phases for separation of enantiomers in chiral media. Also these polymers are superior to some sorbents such as polyelectrolytes due to their insolubility in water and their ability to use in aqueous ionic media. 


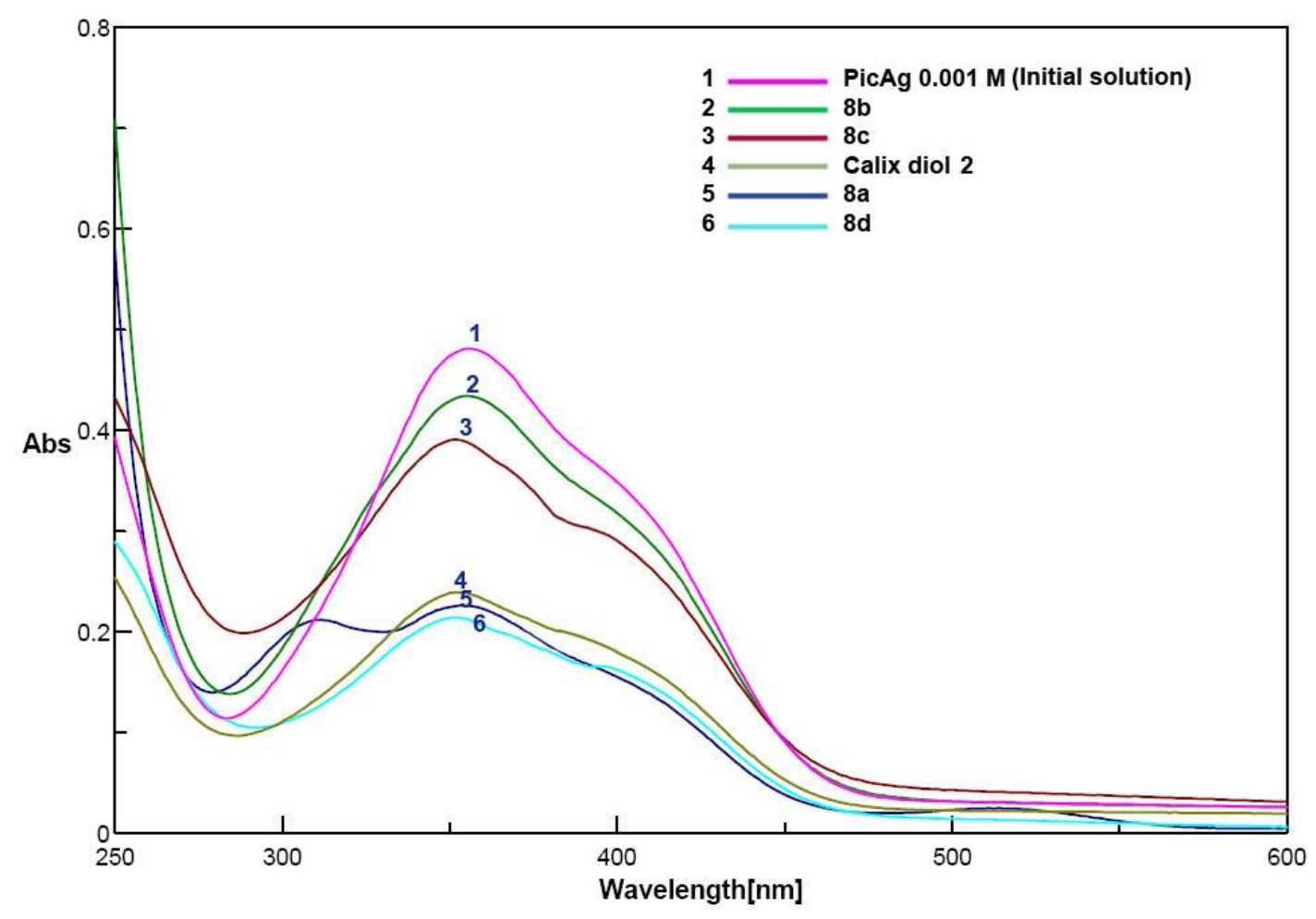

Fig. 7. UV curves for initial and final aqueous solutions containing $\mathrm{Ag}^{+}$.

\section{Conclusions}

We have demonstrated that the macrocycles, such as calix[4]arene diol (2) can be polymerized with optically active imide containing diacid chlorides to give optically active PEls. The main goal of this work is introducing optically active amino acid moiety in the calix[4]arene based polymer chain. Thus we combined the characteristics of ester-imide groups with extraction ability of calix[4]arene. In this design we achieved valuable results: optical activity, good solubility in solvents like chloroform and dichloromethane as well as good inherent viscosity and thermal stability. The different polymerization methods influenced the chemical and physical properties of the corresponding polymers. These PEls are a new family of useful polymeric materials for ion exchange studies and separation of enantiomers in chiral media.

\section{Experimental}

\section{Materials and methods}

Pyromellitic dianhydride (3) and amino acids were from Merck Co. and used without further purification. Dichloromethane was dried over $\mathrm{CaCl}_{2}$. Reactions were monitored by TLC on silica gel. $\mathrm{NaNO}_{3}, \mathrm{KNO}_{3}, \mathrm{CsNO}_{3}$, and $\mathrm{AgNO}_{3}$ were purchased from Merck and were used as received. $p$-Tert-butyl calix[4]arene (1) was prepared as described [8].

\section{Characterization}

IR spectra were recorded on a $\mathrm{FT} / \mathrm{IR}-680$ plus spectrophotometer using $\mathrm{KBr}$ pellets. Band intensities are assigned as weak ( $\mathrm{w})$, medium (m), and strong (s). Band shapes 
assigned as shoulder (sh), sharp (s), and broad (br). Inherent viscosities were measured by a standard procedure using a Cannon Fenske routine viscometer at 25 ${ }^{\circ} \mathrm{C}$ using DMF as solvent. ${ }^{1} \mathrm{H}$ NMR spectra were recorded on $500 \mathrm{MHz}$ instrument, using $\mathrm{CDCl}_{3}$ as solvent and tetra methyl silane as shift reference (tube diameter 5 $\mathrm{mm}$ ). Specific rotations were measured by a JASCO P-1030 Polarimeter. Thermal gravimetric analysis (TGA) was obtained by a Mettler TGA-50 under air atmosphere at a rate of $10{ }^{\circ} \mathrm{C} / \mathrm{min}$. Differential scanning calorimetry (DSC) was obtained by a Mettler DSC-30 under nitrogen atmosphere. Melting points were measured in open capillaries with a Gallenkamp instrument. Elemental analysis was performed by Malek-Ashtar University of Technology, Tehran, Iran. The MicroSynth Milestone Microwave apparatus was used for the reactions under microwave irradiation.

\section{Monomer Synthesis}

- Synthesis of p-t-butyl calix[4]arene diol (distal cone) (2)

A suspension of $p$-t-butyl calix[4]arene $(5.0 \mathrm{~g}, 7.7 \mathrm{mmol})$, anhydrous $\mathrm{K}_{2} \mathrm{CO}_{3}(1.2 \mathrm{~g}$, $8.8 \mathrm{mmol})$ and benzyl bromide $(1.8 \mathrm{ml}, 15.4 \mathrm{mmol})$ in $\mathrm{CH}_{3} \mathrm{CN}(50 \mathrm{ml})$ was refluxed for $20 \mathrm{~h}$. The solvent was removed under reduced pressure, the mixture was treated with $\mathrm{CH}_{3} \mathrm{Cl}(100 \mathrm{ml})$ and washed with $1 \mathrm{~N} \mathrm{HCl}(2 \times 25 \mathrm{ml})$ and brine $(25 \mathrm{ml})$. The organic layer was dried with $\mathrm{MgSO}_{4}$ and evaporated under reduced pressure. The pale yellow solid was washed with cold $\mathrm{CH}_{3} \mathrm{OH}(100 \mathrm{ml})$ to give compound 2 as a white powder $(4.2 \mathrm{~g}, 71.2 \%)$. mp: $194-195{ }^{\circ} \mathrm{C}$. FTIR $\left(\mathrm{KBr}, \mathrm{cm}^{-1}\right): 3419(\mathrm{~s}, \mathrm{br}), 3030(\mathrm{~m})$, 2957 (s), 2865 (s), 1749 (w), $1599(\mathrm{~m}), 1484(\mathrm{~s}), 1454(\mathrm{~s}), 1392(\mathrm{~m}), 1375(\mathrm{~s}), 1361$ (s), $1301(\mathrm{~s}), 1206(\mathrm{~s}), 1122(\mathrm{~s}), 1096(\mathrm{~m}), 1078(\mathrm{w}), 1018(\mathrm{~s}), 994(\mathrm{~m}), 944(\mathrm{~m}), 916$ $(\mathrm{m}), 887(\mathrm{w}), 871(\mathrm{~s}), 818(\mathrm{w}), 788(\mathrm{w}), 755(\mathrm{~m}), 730(\mathrm{~s}), 693(\mathrm{~m}) .{ }^{1} \mathrm{H}$ NMR $(500 \mathrm{MHz}$, $\left.\mathrm{CDCl}_{3}, 25^{\circ} \mathrm{C}\right): \delta 0.99(\mathrm{~s}, 18 \mathrm{H}), 1.33(\mathrm{~s}, 18 \mathrm{H}), 3.31(\mathrm{~d}, 4 \mathrm{H}, \mathrm{J}=13.1 \mathrm{~Hz}), 4.33(\mathrm{~d}, 4 \mathrm{H}, \mathrm{J}=$ $13.0 \mathrm{~Hz}), 5.10(\mathrm{~s}, 4 \mathrm{H}), 6.83(\mathrm{~s}, 4 \mathrm{H}), 7.09(\mathrm{~s}, 4 \mathrm{H}), 7.30(\mathrm{~s}, 2 \mathrm{H}), 7.40-7.42(\mathrm{~m}, 3 \mathrm{H})$, 7.68-7.70 (m, 2H).

\section{- Synthesis of diacids (6a-6e): general procedure}

Into a $25-\mathrm{ml}$, round-bottomed flask $5.61 \mathrm{mmol}$ of pyromellitic dianhydride (3), 11.2 mmol of amino acids (5a-5e), $15.0 \mathrm{ml}$ of acetic acid and a stirring bar were placed. The mixture was stirred at room temperature overnight then was refluxed for $6 \mathrm{~h}$. The solvent was removed under reduced pressure and $10 \mathrm{ml}$ of cold concentrated $\mathrm{HCl}$ was added to the residue. A white precipitate was formed, filtered off, washed with a large amount of water and dried under vacuum at $100^{\circ} \mathrm{C}$ to give compounds (6a-6e). Recrystallization from methanol/water gave pure crystals.

Diacid (6a): White crystals. Yield $(\%)=96 \%$. mp: $265-266{ }^{\circ} \mathrm{C} . \quad[\alpha]_{\mathrm{D}}^{25}=-29.02^{\circ}[0.050$ $\mathrm{g}$ in $10 \mathrm{ml}$ acetone]. IR $\left(\mathrm{KBr}, \mathrm{cm}^{-1}\right): 2400-3500(\mathrm{~m}, \mathrm{br}), 1778(\mathrm{~s}), 1714(\mathrm{~s}, \mathrm{br}), 1458$ $(\mathrm{m}), 1383(\mathrm{~s}), 1363(\mathrm{~s}), 1251(\mathrm{~s}), 1170(\mathrm{~m}), 1078(\mathrm{~m}), 1022(\mathrm{~m}), 927(\mathrm{~m}), 850(\mathrm{~m})$, $817(\mathrm{~m}), 767$ (w), $730(\mathrm{~s}), 671(\mathrm{w}), 619(\mathrm{~m}), 565(\mathrm{w}) \mathrm{cm}^{-1}$. ' $\mathrm{H}$ NMR $(300 \mathrm{MHz}$, DMSOd6) $\delta 1.6(\mathrm{~d}, 6 \mathrm{H}), 4.9(\mathrm{q}, 2 \mathrm{H}), 8.3(\mathrm{~s}, 2 \mathrm{H}), 13.4(\mathrm{~s}, 2 \mathrm{H}) \mathrm{ppm}$; Elemental analysis: Calculated for $\mathrm{C}_{6} \mathrm{H}_{12} \mathrm{~N}_{2} \mathrm{O}_{8}$ : C (53.34\%), $\mathrm{H}(3.36 \%), \mathrm{N}(7.77 \%)$; found $\mathrm{C}(52.90 \%), \mathrm{H}$ (3.40\%), N (7.30\%).

Diacid (6b): White crystals. Yield: $90.3 \%$. mp: $291-293^{\circ} \mathrm{C} .[\alpha]_{\mathrm{D}}^{25}=-288.54^{\circ}[0.050 \mathrm{~g}$ in $10 \mathrm{ml}$ acetone]. FTIR $\left(\mathrm{KBr}, \mathrm{cm}^{-1}\right)$ : 2500-3500 (m, br), $1766(\mathrm{~s}), 1722(\mathrm{~s}, \mathrm{br}), 1498(\mathrm{w})$, $1454(\mathrm{~m}), 1384(\mathrm{~s}), 1280(\mathrm{~m}), 1224(\mathrm{~m}), 1178(\mathrm{~m}), 1109(\mathrm{~m}), 1151(\mathrm{w}), 997(\mathrm{w}), 941$ $(\mathrm{m}), 918(\mathrm{w}), 883(\mathrm{w}), 827(\mathrm{~m}), 756(\mathrm{~m}), 733(\mathrm{~m}), 700(\mathrm{~m}), 673(\mathrm{w}), 630(\mathrm{w}), 567(\mathrm{w})$ 
$\mathrm{cm}^{-1} .{ }^{1} \mathrm{H}$ NMR (300 MHz, DMSO-d6) $\delta 3.32$ (dd, 2H), 3.52 (dd, 2H), 5.2 (dd, 2H), 7.2 $(\mathrm{m}, 10 \mathrm{H}), 8.23(\mathrm{~s}, 2 \mathrm{H}) \mathrm{ppm}$; Elemental analysis: Calculated for $\mathrm{C}_{28} \mathrm{H}_{20} \mathrm{~N}_{2} \mathrm{O}_{8}$ : C (65.62\%), H (3.93\%), N (5.46\%); found C (65.30\%), H (4.10\%), N (5.30\%).

Diacid (6c): White crystals. Yield: $80.8 \%$. mp: $292-293{ }^{\circ} \mathrm{C} .[\alpha]_{\mathrm{D}}^{25}=-48.88^{\circ}[0.050 \mathrm{~g}$ in $10 \mathrm{ml}$ acetone]. FTIR $\left(\mathrm{KBr}, \mathrm{cm}^{-1}\right): 3000-3500(\mathrm{~m}, \mathrm{br}), 2960(\mathrm{~m}), 2873(\mathrm{~m}), 1759(\mathrm{~s})$, $1712(\mathrm{~s}), 1469(\mathrm{~m}), 1392(\mathrm{~s}), 1367(\mathrm{~s}), 1273(\mathrm{~m}), 1246(\mathrm{~m}), 1192(\mathrm{~s}), 1153(\mathrm{~s}), 1091$ (s), $1061(\mathrm{~m}), 956(\mathrm{w}), 912(\mathrm{~m}), 866(\mathrm{w}), 829(\mathrm{~m}), 794(\mathrm{~m}), 735(\mathrm{~m}), 671(\mathrm{w}), 652(\mathrm{w})$, $630(\mathrm{~m}), 599(\mathrm{w}), 563(\mathrm{~m}) \mathrm{cm}^{-1} .{ }^{1} \mathrm{H}$ NMR (300 MHz, DMSO-d6) $\delta 0.9(\mathrm{~d}, 12 \mathrm{H}), 1.52$ $(\mathrm{m}, 2 \mathrm{H}), 1.9$ (td, 2H), 2.2 (td, 2H), 4.88 (dd, 2H), 8.3 (s, 2H), 13.4 (s, 2H) ppm; Elemental analysis: calculated for $\mathrm{C}_{22} \mathrm{H}_{24} \mathrm{~N}_{2} \mathrm{O}_{8}$ : C (59.45\%), $\mathrm{H}(5.44 \%), \mathrm{N}(6.30 \%)$; found C (59.10\%), H (5.80\%), N (6.71\%).

Diacid (6d): White crystals. Yield: $81.6 \%$. mp: $266-268^{\circ} \mathrm{C} .[\alpha]_{D}^{25}=-79.10^{\circ}[0.050 \mathrm{~g}$ in $10 \mathrm{ml}$ acetone]. FTIR (KBr): 2500- $3500(\mathrm{~m}, \mathrm{br}), 1774(\mathrm{~s}), 1772(\mathrm{~s}, \mathrm{br}), 1461(\mathrm{~m})$, $1432(\mathrm{~m}), 1384(\mathrm{~s}), 1360(\mathrm{~s}), 1284(\mathrm{~s}), 1153(\mathrm{~m}), 1112(\mathrm{~m}), 1083(\mathrm{~m}), 1012(\mathrm{w}), 895$ $(\mathrm{m}), 835(\mathrm{w}), 814(\mathrm{w}), 779(\mathrm{w}), 734(\mathrm{~m}), 701(\mathrm{w}), 634(\mathrm{~m}), 565(\mathrm{w}) \mathrm{cm}^{-1} .{ }^{1} \mathrm{H}$ NMR $(300$ $\mathrm{MHz}$, DMSO-d6) $\delta 0.95(\mathrm{t}, 6 \mathrm{H}), 1.09(\mathrm{~d}, 6 \mathrm{H}), 1.2(\mathrm{~m}, 4 \mathrm{H}), 2.4(\mathrm{~m}, 2 \mathrm{H}), 4.65(\mathrm{~d}, 2 \mathrm{H})$, $8.4(\mathrm{~s}, 2 \mathrm{H}), 13.2(\mathrm{~s}, 2 \mathrm{H}) \mathrm{ppm}$; Elemental analysis: Calculated for $\mathrm{C}_{22} \mathrm{H}_{24} \mathrm{~N}_{2} \mathrm{O}_{8}$ : C (59.45\%), H (5.44\%), N (6.30\%); found C (59.20\%), H (5.70\%), N (5.90\%).

Diacid (6e): Pale yellow crystals. Yield: $85.1 \%$. mp: $292-294{ }^{\circ} \mathrm{C}$. $[\alpha]_{\mathrm{D}}^{25}=-73.52^{\circ}[0.050$ $\mathrm{g}$ in $10 \mathrm{ml}$ acetone]. FTIR $\left(\mathrm{KBr}, \mathrm{cm}^{-1}\right): 2400-3500(\mathrm{~s}, \mathrm{br}), 1718(\mathrm{~s}, \mathrm{br}), 1440(\mathrm{~m}), 1384$ $(\mathrm{s}), 1367(\mathrm{~s}), 1290(\mathrm{~m}), 1360(\mathrm{~s}), 1217(\mathrm{~m}), 1178(\mathrm{~m}), 1105(\mathrm{~m}), 1012(\mathrm{w}), 929(\mathrm{~m})$, $900(\mathrm{~m}), 833(\mathrm{~m}), 800(\mathrm{w}), 730(\mathrm{~m}), 681(\mathrm{w}), 650(\mathrm{w}), 623(\mathrm{~m}), 565(\mathrm{w}) \mathrm{cm}^{-1}$.

\section{- Synthesis of diacid chlorides (7a-7e): general procedure}

Into a $25 \mathrm{ml}$ round-bottomed flask were placed $0.225 \mathrm{mmol}$ of compounds (6a-6e) and $5 \mathrm{ml}$ (an excess amount) of thionyl chloride. The mixture was refluxed for $3 \mathrm{~h}$. Unreacted thionyl chloride was removed under reduced pressure and the residue was washed with $\mathrm{n}$-hexane, to leave diacid chlorides (7a-7e).

Diacid chloride (7a): White powder. Yield: $92.7 \%$. mp: $243-244{ }^{\circ} \mathrm{C} .[\alpha]_{\mathrm{D}}^{25}=-91.2(0.05$ $\mathrm{g}$ in $10 \mathrm{ml} \mathrm{DMF})$; FTIR (KBr): $3003(\mathrm{~m}), 2947(\mathrm{~m}), 1780(\mathrm{~s}), 1724(\mathrm{~s}, \mathrm{br}), 1454(\mathrm{~m})$, $1383(\mathrm{~s}), 1363(\mathrm{~s}), 1278(\mathrm{w}), 1178(\mathrm{~m}), 1157(\mathrm{~m}), 1128(\mathrm{~m}), 1080(\mathrm{~m}), 1016(\mathrm{~m}), 943$ (s), $900(\mathrm{w}), 879(\mathrm{~m}), 839(\mathrm{~m}), 769(\mathrm{w}), 732(\mathrm{~m}), 696(\mathrm{w}), 603(\mathrm{~m}), 559(\mathrm{w}) \mathrm{cm}^{-1}$. Elemental analysis: Calculated for $\mathrm{C}_{16} \mathrm{H}_{10} \mathrm{~N}_{2} \mathrm{O}_{6} \mathrm{Cl}_{2}$ : C (48.38\%), $\mathrm{H}(2.54 \%), \mathrm{N}(7.05$ $\%)$; Found C (48.29\%), H (2.58\%), N (6.96\%).

Diacid chloride (7b): White powder. Yield: $81.6 \%$. mp: $189-190{ }^{\circ} \mathrm{C} .[\alpha]_{\mathrm{D}}^{25}=-246.6^{\circ}$ [0.050 g in $10 \mathrm{ml}$ acetone]. FTIR (KBr): $3031(\mathrm{~m}), 2912(\mathrm{~m}), 1803(\mathrm{~s}), 1776(\mathrm{~s}), 1728$ (s), $1496(\mathrm{w}), 1456(\mathrm{~m}), 1378(\mathrm{~s}), 1361(\mathrm{~s}), 1205(\mathrm{w}), 1157(\mathrm{w}), 1132(\mathrm{~m}), 1109(\mathrm{~m})$, $1016(\mathrm{~m}), 958(\mathrm{~m}), 920(\mathrm{~m}), 891(\mathrm{~m}), 841(\mathrm{~m}), 783(\mathrm{~m}), 756(\mathrm{~m}), 731(\mathrm{~m}), 702(\mathrm{~m})$, $621(\mathrm{w}), 548(\mathrm{w}), 520(\mathrm{~m}) \mathrm{cm}^{-1}$. Elemental analysis: Calculated for $\mathrm{C}_{28} \mathrm{H}_{16} \mathrm{~N}_{2} \mathrm{O}_{6} \mathrm{Cl}_{2}: \mathrm{C}$ (61.22\%), H (3.30\%), N (5.10\%); Found C (60.98\%), H (3.11\%), N (4.87\%).

Diacid chloride (7c): White powder. Yield: $80.8 \%$. mp: $166-167{ }^{\circ} \mathrm{C} .[\alpha]_{\mathrm{D}}^{25}=-47.86^{\circ}$ [0.050 g in $10 \mathrm{ml}$ acetone]. FTIR $\left(\mathrm{KBr}, \mathrm{cm}^{-1}\right): 3106(\mathrm{~m}), 2962(\mathrm{~m}), 2935(\mathrm{~m}), 2873$ (m), 1807 (s), 1778 (s), 1724 (s, br), 1468 (m), 1381 (s), $1273(\mathrm{w}), 1232(\mathrm{w}), 1170$ $(\mathrm{m}), 1155(\mathrm{~m}), 1118(\mathrm{~m}), 1082(\mathrm{~m}), 1053(\mathrm{~m}), 995(\mathrm{~m}), 937(\mathrm{~m}), 920(\mathrm{~m}), 875(\mathrm{w}), 841$ $(\mathrm{m}), 775(\mathrm{~m}), 736(\mathrm{~m}), 665(\mathrm{w}), 603(\mathrm{~m}), 563(\mathrm{~m}) \mathrm{cm}^{-1}$. Elemental analysis: Calculated 
for $\mathrm{C}_{22} \mathrm{H}_{22} \mathrm{~N}_{2} \mathrm{O}_{6} \mathrm{Cl}_{2}$ : C (54.90\%), $\mathrm{H}(4.61 \%), \mathrm{N}(5.82 \%)$; found $\mathrm{C}(54.68 \%), \mathrm{H}(4.32 \%)$, $\mathrm{N}(5.68 \%)$.

Diacid chloride (7d): White powder. Yield: $81.6 \%$. mp: $143-144{ }^{\circ} \mathrm{C} .[\alpha]_{\mathrm{D}}^{25}=-91.10^{\circ}$ [0.050 g in $10 \mathrm{ml}$ acetone]. FTIR (KBr): $3110(\mathrm{w}), 3052(\mathrm{w}), 2973(\mathrm{~s}), 2937(\mathrm{~m}), 2881$ (m), 1797 (s), 1778 (s), 1724 (s, br), 1461 (m), 1381 (s), 1357 (s), 1247 (m), 1172 $(\mathrm{m}), 1151(\mathrm{~m}), 1128(\mathrm{~m}), 1084(\mathrm{~s}), 1020(\mathrm{~m}), 962(\mathrm{~m}), 895(\mathrm{~m}), 854(\mathrm{~m}), 810(\mathrm{~m}), 765$ $(\mathrm{m}), 733(\mathrm{~s}), 669(\mathrm{w}), 634(\mathrm{~m}), 605(\mathrm{~m}), 561(\mathrm{~m}), 520(\mathrm{w}) \mathrm{cm}^{-1}$. Elemental analysis: Calculated for $\mathrm{C}_{22} \mathrm{H}_{22} \mathrm{~N}_{2} \mathrm{O}_{6} \mathrm{Cl}_{2}$ : C (54.90\%), $\mathrm{H}(4.61 \%), \mathrm{N}(5.82 \%)$; found $\mathrm{C}(54.72 \%)$, $\mathrm{H}(4.31 \%), \mathrm{N}(5.64 \%)$.

Diacid chloride (7e): White powder. Yield: $92.73 \%$. mp: $128-130{ }^{\circ} \mathrm{C}$. $[\alpha]_{\mathrm{D}}^{25}=-63.96$ (0.05 g in $10 \mathrm{ml} \mathrm{DMF);} \mathrm{IR} \mathrm{(KBr):} 2950$ (m), $2923(\mathrm{~m}), 1790$ (s), 1780 (s), 1730 (s), $1485(\mathrm{~m}), 1377$ (s), 1365 (s), $1104(\mathrm{~m}), 837(\mathrm{~m}), 796(\mathrm{w}), 729(\mathrm{~m}), 628(\mathrm{w}), 563(\mathrm{w})$ $\mathrm{cm}^{-1}$. Elemental analysis: Calculated for $\mathrm{C}_{20} \mathrm{H}_{18} \mathrm{~N}_{2} \mathrm{O}_{6} \mathrm{Cl}_{2} \mathrm{~S}_{2}: \mathrm{C}(46.43 \%), \mathrm{H}(3.51 \%), \mathrm{N}$ (5.41\%); found C (46.12\%), H (3.18\%), N (5.11\%).

\section{Polymerization}

- Bulk polycondensation of diacid chloride (7a-7e) with calix[4]arene diol (2) under microwave irradiation (Method 1): general procedure

Into a $10 \mathrm{ml}$ round-bottomed flask compounds $(7 \mathrm{a}-7 \mathrm{e})(0.2 \mathrm{mmol})$ and calix[4]arene diol (2) (0.2 mmol) were added. After mixing thoroughly, the mixture was subjected to microwave irradiation using a power of $1000 \mathrm{~W}$ with temperature of $50{ }^{\circ} \mathrm{C}$ for $3 \mathrm{~min}$, $50-100{ }^{\circ} \mathrm{C}$ for $5 \mathrm{~min}$ and $100-110{ }^{\circ} \mathrm{C}$ for additional $5 \mathrm{~min}$. The reaction was performed under temperature control. The polymer films were washed with methanol $(30 \mathrm{ml})$ to leave PEls (8a-8e).

PEI (8a): FTIR (KBr): 3399 (m, br), 3031 (m), 2959 (s), 2869 (m), 1776 (m), 1729 (s), $1678(\mathrm{~m}), 1598(\mathrm{~m}), 1484(\mathrm{~s}), 1381(\mathrm{~s}), 1362(\mathrm{~s}), 1295(\mathrm{~m}), 1206(\mathrm{~s}), 1121$ (s), 1100 (s), $1009(\mathrm{~m}), 917(\mathrm{~m}), 871(\mathrm{~m}), 819(\mathrm{w}), 781(\mathrm{w}), 753(\mathrm{~m}), 730(\mathrm{~m}), 696(\mathrm{~m}), 607(\mathrm{w})$, $565(\mathrm{w}), \mathrm{cm}^{-1} .{ }^{1} \mathrm{H}$ NMR: $\delta 0.94(\mathrm{~s}, 18 \mathrm{H}), 1.23(\mathrm{~d}, 6 \mathrm{H}, \mathrm{J}=15.5), 1.29(\mathrm{~s}, 18 \mathrm{H}), 3.26(\mathrm{~d}$, $4 \mathrm{H}, \mathrm{J}=13.1), 4.28(\mathrm{~d}, 4 \mathrm{H}, \mathrm{J}=13.1), 4.59-4.76(\mathrm{~m}, 2 \mathrm{H}), 5.05(\mathrm{~s}, 4 \mathrm{H}), 6.78(\mathrm{~s}, 4 \mathrm{H}), 7.04$ (s, 4H), 7.33 (s, br, 6H), 7.35-7.37 (m, 4H), $8.26(\mathrm{~s}, 2 \mathrm{H})$.

PEI (8b): FTIR (KBr): 3338 (m, br), $3031(\mathrm{~m}), 2958(\mathrm{~s}), 2906(\mathrm{~m}), 2867(\mathrm{~m}), 1726(\mathrm{~m})$, $1729(\mathrm{~s}), 1680(\mathrm{~m}), 1600(\mathrm{~m}), 1483(\mathrm{~s}), 1460(\mathrm{~s}), 1363(\mathrm{~m}), 1298(\mathrm{~m}), 1203(\mathrm{~s}), 1122$ (m), $1097(\mathrm{~m}), 1012(\mathrm{~m}), 991(\mathrm{~m}), 945(\mathrm{w}), 914(\mathrm{w}), 871(\mathrm{~m}), 817(\mathrm{w}), 783(\mathrm{w}), 754$ (s), $696(\mathrm{~m}), 634(\mathrm{w}), 590(\mathrm{w}), \mathrm{cm}^{-1} .{ }^{1} \mathrm{H}$ NMR: $\delta 0.94(\mathrm{~s}, 18 \mathrm{H}), 1.29(\mathrm{~s}, 18 \mathrm{H}), 3.05-3.21$ $(\mathrm{m}, 4 \mathrm{H}), 3.26(\mathrm{~d}, 4 \mathrm{H}, \mathrm{J}=13.1), 4.28(\mathrm{~d}, 4 \mathrm{H}, \mathrm{J}=13.1), 4.71-4.80(\mathrm{~m}, 2 \mathrm{H}), 5.05(\mathrm{~s}, 4 \mathrm{H})$, $6.78(\mathrm{~s}, 4 \mathrm{H}), 7.04(\mathrm{~s}, 4 \mathrm{H}), 7.29-7.41(\mathrm{~m}, 20 \mathrm{H}), 8.12(\mathrm{~s}, 2 \mathrm{H})$.

PEI (8c): FTIR (KBr): 3418 (m, br), 3031 (m), 2960 (s), 2868 (s), 1776 (s), 1729 (s), $1600(\mathrm{~m}), 1485(\mathrm{~s}), 1430(\mathrm{~m}), 1381(\mathrm{~s}), 1362(\mathrm{~s}), 1300(\mathrm{~m}), 1206(\mathrm{~s}), 1122(\mathrm{~s}), 1019$ $(\mathrm{m}), 979(\mathrm{~m}), 947(\mathrm{~m}), 917(\mathrm{~m}), 872(\mathrm{~s}), 819(\mathrm{~m}), 780(\mathrm{~m}), 754(\mathrm{~m}), 730(\mathrm{~s}), 695(\mathrm{~s})$, $637(\mathrm{~m}), 619(\mathrm{~m}), 552(\mathrm{~m}), 521(\mathrm{~m}), \mathrm{cm}^{-1} .{ }^{1} \mathrm{H}$ NMR: $\delta 0.93(\mathrm{~d}, 12 \mathrm{H}, \mathrm{J}=10.1), 0.94(\mathrm{~s}$, $18 \mathrm{H}), 1.10-1.28(\mathrm{~m}, 6 \mathrm{H}) . .1 .29(\mathrm{~s}, 18 \mathrm{H}), 3.26(\mathrm{~d}, 4 \mathrm{H}, \mathrm{J}=13.1), 4.28(\mathrm{~d}, 4 \mathrm{H}, \mathrm{J}=13.1)$, 4.91-4.98 (m, 2H), $5.05(\mathrm{~s}, 4 \mathrm{H}), 6.78(\mathrm{~s}, 4 \mathrm{H}), 7.04(\mathrm{~s}, 4 \mathrm{H}), 7.26(\mathrm{~s}, 6 \mathrm{H}), 7.35-7.37(\mathrm{~m}$, $4 \mathrm{H}), 8.26(\mathrm{~m}, 2 \mathrm{H})$.

PEI (8d): FTIR (KBr): 3388 (m, br), 3031 (m), 2961 (s, br), 2870 (s), 1777 (s), 1726 (s), $1638(\mathrm{~m}), 1599(\mathrm{~m}), 1483$ (s), 1462 (s), 1381 (s), 1360 (s), 1298 (s), 1206 (s), $1122(\mathrm{~s}), 1081(\mathrm{~m}), 1009(\mathrm{~s}), 947(\mathrm{~m}), 917(\mathrm{~m}), 889(\mathrm{~m}), 872(\mathrm{~s}), 819(\mathrm{~m}), 780(\mathrm{~m})$, 
$753(\mathrm{~m}), 731(\mathrm{~s}), 696(\mathrm{~s}), 637(\mathrm{~m}), 607(\mathrm{~m}), 565(\mathrm{~m}), 521(\mathrm{~m}), \mathrm{cm}^{-1} .{ }^{1} \mathrm{H}$ NMR: $\delta 0.81$ $(\mathrm{t}, 6 \mathrm{H}), 0.94(\mathrm{~s}, 18 \mathrm{H}), 1.16-1.19(\mathrm{~d}, 6 \mathrm{H}) .1 .29(\mathrm{~s}, 18 \mathrm{H}), 2.51-2.59(\mathrm{~m}, 4 \mathrm{H}), 3.26(\mathrm{~d}, 4 \mathrm{H}$, $\mathrm{J}=13.1), 4.28(\mathrm{~d}, 4 \mathrm{H}, \mathrm{J}=13.1), 4.71-4.76(\mathrm{~m}, 2 \mathrm{H}), 5.05(\mathrm{~s}, 4 \mathrm{H}), 6.78(\mathrm{~s}, 4 \mathrm{H}), 7.04(\mathrm{~s}$, $4 \mathrm{H}), 7.26(\mathrm{~s}, 6 \mathrm{H}), 7.35-7.37(\mathrm{~m}, 4 \mathrm{H}), 8.24(\mathrm{~s}, 2 \mathrm{H}, \mathrm{Ar})$.

PEI (8e): FTIR (KBr): 3398 (m, br), 3031 (m), 2958 (s, br), 2867 (s), 1776 (s), 1728 (s), $1598(\mathrm{~m}), 1484(\mathrm{~s}), 1462(\mathrm{~m}), 1381(\mathrm{~s}), 1362(\mathrm{~s}), 1300(\mathrm{~s}), 1206(\mathrm{~s}), 1122(\mathrm{~s})$, $1104(\mathrm{~s}), 1019(\mathrm{~s}), 979(\mathrm{~s}), 947(\mathrm{~m}), 916(\mathrm{~m}), 871(\mathrm{~s}), 818(\mathrm{~m}), 781(\mathrm{~m}), 753(\mathrm{~m}), 729$ $(\mathrm{s}), 695(\mathrm{~s}), 637(\mathrm{~m}), 592(\mathrm{~m}), 552(\mathrm{~m}), 521(\mathrm{~m}), \mathrm{cm}^{-1} .{ }^{1} \mathrm{H}$ NMR: $\delta 0.83-0.86(\mathrm{~m}, 6 \mathrm{H})$, $0.95(\mathrm{~s}, 18 \mathrm{H}), 1.29(\mathrm{~s}, 18 \mathrm{H}), 1.32-1.38(\mathrm{~m}, 4 \mathrm{H}) .2 .10-2.14(\mathrm{~m}, 4 \mathrm{H}), 3.26(\mathrm{~d}, 4 \mathrm{H}, \mathrm{J}=$ 13.1), $4.28(\mathrm{~d}, 4 \mathrm{H}, \mathrm{J}=13.1), 4.91-4.98(\mathrm{~m}, 2 \mathrm{H}), 5.05(\mathrm{~s}, 4 \mathrm{H}), 6.79(\mathrm{~s}, 4 \mathrm{H}), 7.04(\mathrm{~s}$, $4 \mathrm{H}), 7.26(\mathrm{~s}, 6 \mathrm{H}), 7.35-7.37(\mathrm{~m}, 4 \mathrm{H}), 8.01(\mathrm{~s}, 2 \mathrm{H})$.

- Solution polycondensation of monomers (7a-7e) and calix[4]arene diol (2) (Method 2): general procedure

In a solution of diol (2) $(0.2 \mathrm{mmol})$ in dry $\mathrm{CH}_{2} \mathrm{Cl}_{2}(5 \mathrm{ml})$ in the presence of TEA $(0.2$ $\mathrm{ml}, 1.4 \mathrm{mmol}$ ) was added drop wise the solution of diacid chlorides (7a-7e) $(0.2$ $\mathrm{mmol})$ in dry $\mathrm{CH}_{2} \mathrm{Cl}_{2}(3 \mathrm{ml})$ at room temperature. The solution was stirred at room temperature for $30 \mathrm{~min}$ and then was refluxed for $1 \mathrm{~h}$. During this time the polymer precipitates appeared. The solvent was reduced and methanol $(20 \mathrm{ml})$ was added. The polymer powders (9a-9e) were filtered and washed with methanol $(20 \mathrm{ml})$ and dried.

\section{- Picrate extraction procedure}

Picrate extraction experiments were performed following the Cram procedure [44]. 5 $\mathrm{ml}$ of an aqueous solutions containing $2.5 \times 10^{-4} \mathrm{M}$ of picric acid (2,4,6-trinitrophenol) and $10^{-2} \mathrm{M}$ of an alkali salt $\mathrm{M}^{+} \mathrm{NO}_{3}$, were added $5 \mathrm{ml}$ of a $2.0 \times 10^{-3} \mathrm{M}$ solution of calix[4]arene derivative polymers (8a-8e) in $\mathrm{CHCl}_{3}$. After vigorous stirring at room temperature for $20 \mathrm{~h}$ in a stoppered glass flask $(10 \mathrm{ml})$, the picrate concentrations in the two solvents were spectrophotometrically monitored at $355 \mathrm{~nm}$ using a PerkinElmer Lambda 6 spectrophotometer equipped with integrating sphere. The salts used for the extraction, $\mathrm{NaNO}_{3}, \mathrm{KNO}_{3}, \mathrm{CsNO}_{3}$ and $\mathrm{AgNO}_{3}$, were reagent grade. No detectable amounts of picrate anions were observed into the organic layer after the extraction without calix[4]arene based polymers. The percent sorption of ion (S \%) has been calculated as

$S(\%)=\left[\frac{C i-C e}{C i}\right] \times 100$

where $\mathrm{Ci}$ and $\mathrm{Ce}$ are the initial and final concentration of metal picrates before and after sorption, respectively.

\section{Acknowledgements}

We gratefully acknowledge the funding support received for this project from Isfahan University of Technology (IUT), IR Iran (ARH). Further financial support from Centre of Excellence in Sensor and Green Chemistry research (IUT) is gratefully acknowledged.

\section{References}

[1] Coppola, G.M.; Schuster, H.F. Asymmetric Synthesis: Construction of Chiral Molecules Using Amino Acids. New York: Wiley, 1987. 
[2] Kelly, J.W. Amino Acids, Peptides, Porphyrins, and Alkaloids in Comprehensive Natural Products Chemistry. England: Oxford, Elsevier, 1999, 4.

[3] Billiot, E.; Warner, I.M. Anal. Chem., 2000, 72, 1740.

[4] Bluhm, L.; Huang, J.M.; Li, T.Y. Anal. Bioanal. Chem., 2005, 382, 592.

[5] Feng, L.; Hu, J.; Liu, Z.H.; Zhao, F.; Liu, G. Polymer, 2007, 48 (13), 3616.

[6] Gutsche C D, Calixarenes, monographs in supramolecular chemistry, Vol 1, Stoddart, J F Ed., The royal Society of Chemistry; Cambridge, 1998.

[7] Gutsche, C.D.; lqbal, M.; Stewart, D. J. Org. Chem., 1986, 51, 742.

[8] Ungaro, R.; Pochini, A.; Andreetti, G.D. J. Inclusion Phenom., 1984, 2, 199.

[9] Izatt, R.M.; Lamb, J.D.; Hawkins, R.T.; Brown, P.R.; Izatt, S.R.; Christensen, J.J. J. Am. Chem. Soc., 1983, 105, 1782.

[10] (a) Bohmer, V. Angew. Chem. Int. Ed. Ingl., 1995, 34, 713.

(b) Shinkai, S.; Takeshita, M. Bull. Chem. Soc. Jpn., 1995, 68, 1088.

[11] Pailleret, A.; Herzog, G.E.; Arrigan, D.W.M. Electrochemistry Commun., 2003, 5, 68.

[12] Oluyomi, A.; Okunola, J.L.; Seganish, K.J.; Salimian, P.Y.; Zavalij, T.D. Tetrahedron, 2007, 63, 10743.

[13] (a) Yimaz, A.; Yilmaz, E.; Yilmaz, M.; Bartsch, R.A. Dyes Pigments, 2007, 74, 54. (b) Nijenhuis, W.F.; Van, Doorm, A.R.; Reichwein, A.M.; De, Jong. F.; Reinhoudt, D.N. J. Am. Chem. Soc., 1991, 113, 3607..

[14] Zhu, W.P.; Ling, J.; Shen, Z.Q. Macromol. Chem. Phys., 2006, 207, 844.

15. Jacob, S.; Majoros, I.; Kennedy, J.P. Macromolecules, 1996, $29,8631$.

[16] Gravett, D.M.; Guillet, J.E. Macromolecules, 1996, 29, 617.

[17] Harris, S.J.; Barrett, G.; Mc Kervey, M.A. J. Chem. Soc. Chem. Commun., 1991, 1224.

[18] Shinkai, S.; Kawaguchi, H.; Manbe, O. J. Polym. Sci. Polym. Lett., 1988, 26, 391.

[19] Klok, H.A.; Eibeck, P.; Moller, M.; Reinhoudt, D.N. Macromolecules, 1997, 30, 795.

[20] Gungor, O.; Memon, S.; Yilmaz, M.; Roundhill, D.M. Reac. Func. Polym., 2005, $63,1$.

[21] Tabakci, M.; Memon, S.; Yilmaz, M.; Roundhill, D.M., J. Polym. Sci. A. Polym. Chem., 2004, 42, 186. (c) Kenis, P.J.A.; Noordman, O.F.J.; van Hulst, N.F.; Engbersen, J.F.J.; Reinhoudt, D.N.; Hams, B.H.M.; van der Vorst, C.P.J.M. Chem. Mater., 1997, 9, 596.

[22] Hill, R.; Walker, E.E. J. Appl. Polym. Sci., 1948, 3, 609.

[23] Maiti, S.; Das, S. J. Appl. Polym. Sci., 1981, 26, 957.

[24] Hus, T.F.; Lin, Y.L.; Lee, Y.D. J. Polym. Sci. Polym. Chem. Ed., 1998, 36, 1791.

[25] Mallakpour, S.E.; Hajipour, A.R.; Habibi, S. Eur. Polym. J., 2001, 37, 2435.

[26] Mallakpour, S.; Shahmohammadi, M.H. Polym. Int., 2004, 53, 184.

[27] Mallakpour, S.E.; Hajipour, A.R.; Habibi, S. J. Appl. Polym. Sci., 2002, 86, 2211.

[28] Sinnwell, S.; Ritter, H. Macromo. Rapid Commun., 2004, 26, 160.

[29] Anastas, P.T.; Heine, L.; Williamson, T. Green Chemical Syntheses and Processes, American Chemical Society, Washington DC, 2000.

[30] Mallakpour, S.; Kowsari, E. J. Polym. Sci. Part A: Polym. Chem., 2003, 41, 3974. [31] Gebye, R.; Smith, F.; Westaway, K.; Ali, H.; Baldisera, L.; Laberge, L.; Rousell, J. Tetrahedron Lett., 1986, 27, 279.

[32] Gebye, R.; Bray, T.; Duncan, S.; Majetich, G. Tetrahedron Lett., 1986, 27, 4945.

[33] (a) Araki, K.; Iwamoto, K.; Shinkai, S.; Matsuda, T. Chem. Lett., 1989, 1747. (b)

Iwamoto, K.; Araki, K.; Shinkai, S. J. Org. Chem., 1991, 56, 4955. 
[34] Collins, E.M.; McKervey, M.A.; Madigan, E.; Moran, M.B.; Owens, M.; Ferguson, G.; Harris, S.J. J. Chem. Soc. Perkin. Trans. 1, 1991, 3137.

[35] (a) Bo"hmer, A. Angew. Chem, Int. Ed. Engl., 1995, 34, 713. (b) Gutsche, C.D. Aldrichimica Acta. 1995, 28, 3. (c) Gutsche, C.D. Calixarenes revisited. Cambridge: The Royal Society of Chemistry, 1998.

[36] Ikeda, A.; Tsuzuki, H.; Shinkai, S. J. Chem. Soc. Perk. Trans. 2, 1994, 2073.

[37] Ikeda, A.; Shinkai, S. J. Am. Chem. Soc., 1994, 116, 3102.

[38] Koeing, K.E.; Lein, G.M.; Stuckler, P.; Kaneda, T.; Cram, D.J. J. Am. Chem. Soc. 1979, 101, 3553.

[39] (a) Beer, P.D.; Martin, J.P.; Drew, M.G.B. Tetrahedron, 1992, 48, 9917. (b) Matt, D.; Loeber, C.; Vicenes, J.; Asfari, Z. J. Chem. Soc. Chem. Commun., 1993, 604.

[40] Ma, J.C.; Dougherty, D.A. Chem. Rev., 1997, 97, 1303.

[41] Ikeda, A.; Nagasaki, T.; Araki, K.; Shinkai, S. Tetrahedron, 1992, 48, 1059.

[42] Ikeda, A.; Shinkai, S. Chem. Rev., 1997, 97, 1713.

[43] Nabeshima, T.; Aoki, T.; Yano, Y. Tetrahedron Lett., 1997, 38, 8323.

[44] (a) Koening, K.E.; Lein, G.M.; Stuckler, P.; Kaneda, T.; Cram, D.J. J. Am. Chem. Soc., 1979, 101, 3553. (b) Helgeso, R.C.; Weisman, G.R.; Toner, J.L.; Tarnowski, T.L.; Chau, L.; Mayer, J.M.; Cram, D.J. J. Am. Chem. Soc., 1979, 101, 4928. (c) Lein, G.M.; Cram, D.J. J. Am. Chem. Soc., 1985, 107, 448. 